\title{
Understanding Remedy-Stripping Arbitration Clauses: Validity, Arbitrability, and Preclusion Principles
}

By David S. Schwartz*

$\mathbf{I}_{\mathrm{N}}$ N STIRLEN V. SUPERCUTS, ${ }^{1}$ defendant Supercuts moved to compel arbitration of plaintiff Stirlen's state statutory and common law claims pursuant to an arbitration clause that made very clear its intent to deprive Stirlen of most of his remedies:

[I]n the event there is any dispute arising out of [Stirlen's] employment with the Company, the termination of that employment, or arising out of this Agreement, whether such dispute gives rise or may give rise to a cause of action in contract or tort or based on any other theory or statute, including but not limited to [named state and federal anti-discrimination statutes] or any other act or statute, [Stirlen] and the Company agree that exclusive recourse shall be to submit any such dispute to final and binding arbitration ....

[I] $\mathbf{n}$ arbitration, the exclusive remedy for alleged violation of this Agreement or the terms conditions, or covenants of employment, and for any harm alleged in connection with any dispute subject to arbitration hereunder (including, without limitation, causes of action arising in tort), shall be a money award not to exceed the amount of actual damages for breach of contract, less any proper offset for mitigation of such damages, and the parties shall not be entitled to any other remedy at law or in equity, including but not limited to other money damages, exemplary damages, specific performance, and/or injunctive relief. ${ }^{2}$

There is no doubt that the overzealous drafters of this arbitration clause intended to gain enforcement of an otherwise illegal exculpatory or "remedy-stripping" clause by grafting it onto the arbitration provision. Their hope was that the courts' enthusiasm for enforcing arbitration clauses would spill over onto the logically separable rem-

* Assistant Professor of Law, University of Wisconsin Law School. Thanks to Stephen Ware and Jean Sternlight for their comments on this Article.

1. 60 Cal. Rptr. 2d 138 (Ct. App. 1997).

2. Id. at $142-43$. 
edy limitation, one that would have had no chance of enforcement without the arbitration clause.

Courts have not been taken in: they have uniformly refused to enforce such remedy-stripping clauses to deprive the non-drafting party of substantive rights and remedies. But the particular approaches courts have taken to non-enforcement have varied. Moreover, courts have made little, if any, attempt to analyze the preclusion issues that stand directly behind these remedy-stripping arbitration provisions.

How is it, exactly, that a remedy-stripping arbitration clause could ever deprive a plaintiff-as in the above example-of the rights to tort and statutory damages for the employer's intentional wrongs? The necessary assumption is that any claims that might arise respecting the employment, which the arbitration clause says must be arbitrated, will be concluded by the arbitration award; therefore the arbitration would be res judicata in any subsequent action by the plaintiff to obtain the excluded remedies in court. But this assumption appears to be unfounded. Preclusion principles-both res judicata and collateral estoppel-will generally deny full preclusive effect to prior proceedings in which such remedies were excluded. ${ }^{3}$

In this article, I argue that a full understanding of the legal implications of remedy-stripping arbitration clauses in adhesion contracts, and the manner in which courts handle them, requires careful attention to the background principles of res judicata and collateral estoppel. In many cases, courts treat remedy-stripping clauses as "arbitrability" questions, denying arbitration of claims that carry the excluded remedies while compelling arbitration of the others. As a result, a plaintiff finds herself with intertwined arbitrable and nonarbitrable claims. ${ }^{4}$ Because federal law requires the arbitration to pro-

3. The term "res judicata" is often used broadly to refer collectively to the various preclusive effects of former adjudication, and is often used in the narrower sense to refer to what is often called claim preclusion. See Baker v. Gen. Motors Corp., 522 U.S. 222, 233 n.5 (1998); Migra v. Warren City Sch. Dist., 465 U.S. 75, 77 n.1 (1984). In this article, for the sake of clarity, I use the term res judicata only in its narrower sense, interchangeably with "claim preclusion," and I use the terms "collateral estoppel" and "issue preclusion" interchangeably. See Baker, 522 U.S. at 233 n.5.

4. The issue also arises in at least two other contexts. First, the arbitration agreement may expressly limit arbitrability to certain issues. See, e.g., Lagatree v. Luce, Forward, Hamilton \& Scripps, 88 Cal. Rptr. 2d 664, 668 (Ct. App. 1999) (clause expressly limited arbitrability to common law contract and tort claims, while excluding arbitration of statutory claims); Wolf v. Gruntal \& Co., 45 F.3d 524, 525 (1st Cir. 1995) (arbitration agreement excluded federal Rule 10b-5 securities fraud claims). Second, background law may hold that a particular claim is not arbitrable, notwithstanding the language of the agreement. 
ceed first, ${ }^{5}$ questions arise as to the preclusive effect of the arbitration on the subsequently litigated claims. But these questions have received only scant treatment from courts and commentators. ${ }^{6}$

The need to understand preclusion principles in this context has become particularly acute in light of recent legal developments. During the October 2002 term, the Supreme Court decided a trio of arbitration cases, two of which involved remedy-stripping arbitration clauses. ${ }^{7}$ Although none of the decisions resolved whether such remedy-stripping clauses are enforceable, they will affect the way in which these remedy-stripping issues will be resolved in the future. At the same time, drafters of remedy-striping arbitration clauses have devised a new argument that remedy-stripping clauses should be enforced "as written" under the Federal Arbitration Act ("FAA"). Hitherto, lower courts have frequently applied general state unconscionability doctrine to deny enforcement of remedy-stripping clauses. But some defendants have argued that the FAA's purported mandate that arbitration clauses must be enforceable "as written" preempts state contract doctrines that would deny enforcement to remedy-stripping clauses. This argument, though misguided, may be gaining some traction in the courts. If there is any serious possibility of judicial acceptance of a doctrine to enforce remedy-stripping clauses "as written," it is crucial to have worked through the issue of the preclusive effect of an arbitration conducted under such an agreement.

In Part I of this article, I outline the problem of remedy-stripping arbitration clauses: what forms these clauses take, and why courts have not enforced them as intended by their drafters. In brief, there is no exception in the law of arbitration agreements to the well-established

See Duffield v. Robertson, Stephens \& Co., 144 F.3d 1182 (9th Cir. 1998) (holding that Title VII claims are not arbitrable), overruled by EEOC v. Luce, Forward, Hamilton \& Scripps, 345 F.3d 742 (9th Cir. 2003) (en banc); Cruz v. PacifiCare Health Sys., Inc., 66 P.3d 1157 (Cal. 2003) (public injunction claims not arbitrable). Such cases holding claims non-arbitrable as a matter of statutory policy are unusual.

5. See Dean Witter Reynolds Inc. v. Byrd, 470 U.S. 213 (1985); see also text accompanying notes $175-85$.

6. An article that has thoughtfully examined the broader issue of res judicata of arbitration awards, without looking at the problem of remedy-stripping arbitration clauses in particular, is G. Richard Shell, Res Judicata and Collateral Estoppel Effects of Commercial Arbitration, 35 UCLA L. Rev. 623 (1988); see also Anthony G. Buzbee, When Arbitrable Claims are Mixed with Nonarbitrable Ones: What's a Court to Do?, 39 S. Tex. L. Rev. 663 (1998).

7. See Howsam v. Dean Witter Reynolds, Inc., 123 S. Ct. 588 (2003); PacifiCare Health Sys. v. Book, 123 S. Ct. 1531 (2003); Green Tree Fin. Corp. v. Bazzle, 123 S. Ct. 2402 (2003). The arbitration clause purportedly banning class actions in Bazzle is not always viewed as a remedy-stripping clause, but I argue that it is. See infra text accompanying notes 45-46 and discussion infra Part IV.E. 
policy against enforcing prospective contractual waivers of substantive rights in adhesion contracts.

In Part II, I examine the three judicial approaches, prior to the 2002 arbitration trilogy, of denying enforcement to remedy-stripping arbitration clauses. To date, courts have either held the entire arbitration clause unconscionable and therefore unenforceable; severed the offending remedy-stripping terms, to enforce a "cleaned up" arbitration clause without remedy limitations; or enforced the remedy limitations while holding that arbitration will proceed only on those claims for which the arbitrator is authorized to award remedies. I argue that, although proper understanding of preclusion principles places the validity of remedy-stripping clauses in a different light, courts are still justified in striking remedy-stripping clauses in their entirety as unconscionable or against public policy.

In Part III, I consider what impact the trilogy of arbitration cases decided by the Supreme Court in its 2002-03 term has on the question of whether remedy-stripping clauses are enforceable. All three cases deal with a reviewing court's power to decide purported "arbitrability" questions, and two cases specifically raise arbitrability issues in the context of remedy-stripping clauses. Although the Court's decisions are somewhat confusing, and despite some superficial indications to the contrary, these decisions leave undisturbed the courts' power to decide enforceability questions raised by remedy-stripping clauses in most situations. Moreover, the trilogy can best be understood as resting on a distinction between two different enforceability questions: "validity" (the enforceability in toto of an arbitration clause) and "issue-arbitrability" (whether specific kinds of claims or issues can be ordered into arbitration under the agreement). This distinction becomes helpful to a clear understanding of remedy-stripping clauses.

Finally, in Part IV, I examine how preclusion principles should guide courts in cases where a remedy-stripping clause is applied to allow arbitration of some claims and disallow arbitration of others. This mixed or "intertwined" approach will typically raise the question of what preclusive effect the arbitration of, for instance, a contract claim will have on subsequently litigated tort and statutory claims. I argue that courts should give the prior arbitration in such circumstances the narrowest preclusive scope that is consistent with established preclusion principles. Finally, I show how taking preclusion principles into account can also resolve the special remedy-stripping problem of class actions. Although some courts and commentators view a class action ban in an arbitration clause as a question separate 
from clauses that strip damages remedies, I argue that the important substantive consequences of the right to proceed as a class makes the problem of class actions indistinguishable from the remedy-stripping problem in general.

\section{The Problem of Remedy-Stripping Arbitration Clauses}

Courts have consistently refused to enforce remedy-stripping arbitration clauses in the manner intended by the drafters of those clauses. Under well-established common law and statutory policies, courts routinely deny enforcement of adhesion contracts that purport to extract a waiver of future substantive rights or remedies from the adhering or "non-drafting" party-often one who is the beneficiary of a regulatory statute. Neither the FAA nor the judicial enthusiasm for enforcing arbitration agreements in general has created an exception to this rule.

\section{A. The Policy Against Enforcing Remedy-Stripping Clauses in General}

Under common law principles and numerous statutes, prospective waivers of substantive rights are generally disfavored. ${ }^{8}$ Prospective waivers, also known as "exculpatory clauses," "limitation of liability clauses," - or "remedy-stripping clauses," in this article-can take a variety of forms, but share, as a common and defining feature, an intention to limit the drafting party's liability for future torts or statutory violations. ${ }^{9}$ Courts generally refuse to enforce contract clauses whose effect is to exempt a party from liability for its own future fraud or intentional torts, violations of statute, and injuries caused by gross negligence or recklessness. ${ }^{10}$ Common law doctrine is particularly re-

8. For an examination of the rationale underlying the policy against prospective waivers, see David S. Schwartz, Enforcing Small Print to Protect Big Business: Employee and Consumer Rights Claims in an Age of Compelled Arbitration, 1997 WIS. L. Rev. 33, 113-19. In that article, I argue that plain, pre-dispute arbitration clauses are in themselves prospective waivers of substantive rights, insofar as compelled arbitration tends, over the run of cases, to lessen liability of the corporate defendants who impose such agreements. While 1 still believe that analysis is correct, the present article considers only those arbitration agreements that seek to limit or exclude particular remedies.

9. Id. at 112. See, e.g., 6A Arthur Linton Corbin, Corbin on Contracts: A Comprehensive Treatise on the Working Rules of Contract Law $\$ 1515$ (1962).

10. See, e.g., Mitsubishi Motors Corp. v. Soler Chrysler-Plymouth, Inc., 473 U.S. 614, 637 n.19 (1985); Cal. Civ. Code $\$ 1668$ (West 1985); Restatement (Second) of ConTRACTS $\$ 195(1)$ (1981); CoRBIN, supra note 9, 1515 at 727-29; Anita Cava \& Dawn Wiesner, Rationalizing a Decade of Judicial Responses to Exculpatory Clauses, 28 SANTA CLARA L. REv. 611, 613 (1988). 
strictive of prospective waivers where a regulated party seeks to limit its liability to the party benefiting from the regulation-such as consumer or employment contracts. ${ }^{11}$

Similarly, exculpatory clauses have been rejected where they would result in stripping a party of rights and remedies guaranteed by statute. Many regulatory statutes-particularly those protecting consumers or investors-contain "anti-waiver" provisions that expressly guarantee against contract terms purporting to waive the statutes' protections. ${ }^{12}$ Even without such statutory provisions, prospective waivers of such statutory protections are routinely struck down as unconscionable, ${ }^{13}$ void as against public policy, ${ }^{14}$ or simply because they would " "nullify the purposes' of the statute." 15 The principle is sufficiently clear and uncontroversial that the Supreme Court could flatly assert, without further explanation, "To begin, we think it clear that there can be no prospective waiver of an employee's rights under Title VII."16

Where it applies, this general public policy against prospective waivers operates to invalidate not only contract clauses purporting to eliminate liability for future wrongs, but also clauses tending to limit liability, even partially or indirectly-such as through damages caps or restrictions on remedies. ${ }^{17} \mathrm{~A}$ term in an adhesion contract providing that the corporate defendant is not liable for tort or punitive damages would plainly run afoul of the policy against prospective waivers, and would routinely be denied enforcement by the courts. Courts properly

11. See Restatement (Second) of Contracts at $\$ 195$ (2) (a), (e).

12. See, e.g., Securities Act of $1933 \$ 14$, 15 U.S.C. $\$ 77 \mathrm{n}(2001)$; Wisconsin Consumer Act, WIS. STAT. $\$ 421.106(1)$ (1998) (providing that "a customer may not waive or agree to forego rights or benefits under [the Wisconsin Consumer Act]").

13. See, e.g., Stirlen v. Supercuts, Inc., 60 Cal. Rptr. 2d 138 (Ct. App. 1997); Armendariz v. Found. Health Psychcare Servs., Inc., 6 P.3d 669 (Cal. 2000).

14. See Cal. Civ. Code $\$ 1668$; Restatement (Second) of Contracts $\$ 195$.

15. Barrentine v. Arkansas-Best Freight Sys. Inc., 450 U.S. 728, 740 (1981) (quoting Brooklyn Sav. Bank v. O’Neil, 324 U.S. 697, 707 (1945)).

16. Alexander v. Gardner-Denver Co., 415 U.S. 36, 51 (1974).

17. See, e.g., Graham Oil Co. v. ARCO Prods. Co., 43 F.3d 1244 (9th Cir. 1994) (limitation of remedies); Sommer v. Fed. Signal Corp., 593 N.E.2d 1365, 1370-71 (N.Y. 1992) (damages cap); see also 46 U.S.C. app. $\$ 183 \mathrm{c}$ (a) (2000) (declaring "against public policy and ... null and void" any contract provision purporting to "weaken, or avoid the right of any claimant to a trial by court of competent jurisdiction on the question of liability for such loss or injury, or the measure of damages therefor"); CAL. CIv. CoDE $\S 1668$ (prohibiting clauses that "directly or indirectly" exempt a party from intentional tort and statutory liability); Carnival Cruise Lines, Inc. v. Shute, 499 U.S. 585, 599 (1991) (Stevens, J., dissenting) (discussing various contract clauses "designed to put a thumb on the [defendant's] side of the scale of justice"). 
consider damages remedies-including punitive damages-to be "important substantive right[s]."18

Can a prospective waiver - a remedy-stripping clause-be enforced if it is folded into an arbitration agreement? Does the purported "national policy favoring arbitration" that has been read into the FAA in the last two decades create an exception to the policy against prospective waivers? ${ }^{19}$ Drafters of arbitration clauses have certainly experimented with this idea, typically by drafting provisions that seek to limit remedies against them above and beyond the choice of arbitration over litigation itself. But it is plain that the FAA creates no such exception. To the extent that enforcement of a contractual choice of arbitration over a judicial forum is in any sense "favored," nothing in the FAA suggests that that favoritism should extend to such logically separate issues as the damages remedies that will be available or whether the case should proceed as a class action.

The United States Supreme Court has not ruled on these issues directly. However, in the context of endorsing arbitrability of federal statutory claims, the Court has been careful to point out that a party compelled to arbitrate "does not forgo . . . substantive rights," but "only submits to their resolution in an arbitral, rather than a judicial, forum."20 The Court in Mitsubishi Motors Corp. v. Soler Chrysler-Plymouth, Inc., ${ }^{21}$ while holding that anti-trust claims could be compelled into arbitration, cautioned that "[i]n the event the choice-of-forum and choice-of-law clauses operated in tandem as a prospective waiver of a party's right to pursue statutory remedies for antitrust violations, we would have little hesitation in condemning the agreement as against

18. Mastrobuono v. Shearson Lehman Hutton, Inc., 514 U.S. 52, 63 (1995) (noting that the right to punitive damages is "an important substantive right").

19. See Southland Corp. v. Keating, 465 U.S. 1, 10 (1984). While the majority view that the FAA creates a national policy favoring arbitration seems unshakeable at the present moment, it is nevertheless controversial-and, in my view, quite wrong. See, e.g., Circuit City Stores v. Adams, 532 U.S. 105, 132 (2001) (Stevens, J., dissenting) ("There is little doubt that the Court's interpretation of the Act has given it a scope far beyond the expectations of the Congress that enacted it"); Allied Bruce Terminix Cos. v. Dobson, 513 U.S. 265, 283 (1995) ("the Court has abandoned all pretense of ascertaining congressional intent with respect to the [FAA], building instead, case by case, an edifice of its own creation"); David S. Schwartz, Correcting Federalism Mistakes in Statutory Interpretation: The Supreme Court and the Federal Arbitration Act, 67 LAw \& ConTemp. Probs. (forthcoming Winter/ Spring 2004); Jean R. Sternlight, Rethinking the Constitutionality of the Supreme Court's Preference for Binding Arbitration: A Fresh Assessment of Jury Trial, Separation of Powers, and Due Process Concerns, 72 Tul. L. Rev. 1 (1997).

20. E.g., Gilmer v. Interstate/Johnson Lane Corp., 500 U.S. 20, 26 (1991) (quoting Mitsubishi Motors Corp. v. Soler Chrysler-Plymouth, Inc., 473 U.S. 614, 628 (1985)).

21. 473 U.S. 614. 
public policy."22 Remedy-stripping provisions in arbitration clauses present the precise situation anticipated and condemned in Mitsub$i s h$. The arbitration provision-which is "effectively a forum selection clause"23_operates in tandem with the limitation of remedies in an effort to effect "a prospective waiver of a party's right to pursue statutory [or common law] remedies[.]"24 In light of these principles, courts have consistently refused to enforce remedy-stripping provisions.

\section{B. Remedy-Stripping Arbitration Clauses: Examples}

Remedy-stripping arbitration clauses come in a variety of shapes and sizes. Variations include the remedies that are excluded by the arbitration clause and the clarity of the drafting party's intent to impose an illegal pre-dispute waiver. One of the clearer and more egregious remedy-stripping provisions was found in Stirlen. ${ }^{25}$ The clause spelled out that, aside from contract damages, Stirlen would "not be entitled to any other remedy at law or in equity, including but not limited to other money damages, exemplary damages, specific performance, and/or injunctive relief," even though he was required to bring all his claims before the arbitrator, including tort and statutory claims that would provide such remedies. ${ }^{26}$ Even the defendant conceded the illegality of the provision, making a belated offer to Stirlen to waive it and go forward with a "fair" arbitration. ${ }^{27}$ But the Court concluded that this remedy-stripping aspect of the arbitration clause-together with additional terms purporting to shorten the statute of limitations for Stirlen's claims and to preserve, one-sidedly, Supercuts's own access to a judicial forum for its possible claims against Stirlen-was unconscionable. ${ }^{28}$

22. Id. at 637 n.19.

23. EEOC v. Waffle House, 534 U.S. 279, 295 (2002).

24. Mitsubishi, 473 U.S. at 637 n.19.

25. Stirlen v. Supercuts, 60 Cal. Rptr. 2d 138 (Ct. App. 1997); see supra text accompanying note 2.

26. Stirlen, 60 Cal. Rptr. 2d at 143.

27. See id. A similar remedy-stripping clause was found invalid in Armendariz $v$. Foundation Health Psychcare Services, Inc., 6 P.3d 669, 699 (Cal. 2000), in which the employer required its employees to sign arbitration clauses providing that all claims relating to employment termination would be arbitrated and that "in any such arbitration, my exclusive remedies ... shall be limited to a sum equal to the wages I would have earned from the date of any discharge until the date of the arbitration award. I understand that I shall not be entitled to any other remedy, at law or in equity, including but not limited to reinstatement and/or injunctive relief." Id. at 675.

28. See id. at 699 
A perhaps more common example, only slightly less blunt than the Stirlen clause, is an arbitration clause stating that binding arbitration is the "exclusive" remedy for all claims but that, in arbitration, certain kinds of damages cannot be awarded. For example, in Paladino v. Avnet Computer Technologies, ${ }^{29}$ another employment case, the arbitration clause provided that the parties "consent to the settlement by arbitration of any controversy or claim arising out of or relating to ... [Paladino's] employment or termination of . . . [her] employment." 30 Arbitration agreements referring to claims "arising out of or relating to" the employment or consumer contract in question are generally deemed to be "all inclusive," encompassing contract, tort, and statutory claims, ${ }^{31}$ and the Paladino court so understood this clause. ${ }^{32}$

The Paladino clause went on to state that "the arbitrator is authorized to award damages for breach of contract only, and shall have no authority whatsoever to make an award of other damages." 33 The Paladino clause differs from the Stirlen clause in two respects. In Paladino, the remedies limitation is couched in terms of the arbitrator's authority, rather than, as in Stirlen, in terms of the plaintiff's entitlement. Additionally, the remedies limitation in Paladino does not take special pains, as did the Stirlen clause, to reiterate that only contract-type damages are available for statutory or tort claims. Nevertheless, the remedy-stripping import of the clause is clear: the arbitrator is to resolve all claims, but the possible remedies are to be significantly curtailed.

29. 134 F.3d 1054 (11th Cir. 1998).

30. Id. at 1057 .

31. Clauses calling for arbitration of disputes "arising out of" the transaction have tended to be limited to disputes over contract formation or performance, whereas clauses that simply add the phrase "relating to" have been construed as all-inclusive. See Tracer Research Corp. v. Nat'l Envtl. Servs. Co., 42 F.3d 1292, 1295 (9th Cir. 1994); 2 IAN R. Macneil et al., Federal Arbitration Law: Agreements, Awardos \& Remedies Under the Federal Arbitration ACt 20:16-18 (5th ed. 1994). Lower courts have divided over how explicit an arbitration clause must be to notify a party that Title VII and analogous state law claims will be subject to arbitration. Compare Prudential Ins. Co. of Am. v. Lai, 42 F.3d 1299, 1305 (9th Cir. 1994) (holding that general language that does not refer to employment disputes is insufficient to cover arbitration of employment discrimination claims), with Kidd v. Equitable Life Assurance Soc'y, 32 F.3d 516, 520 (11th Cir. 1994) (holding that same language sufficient to compel arbitration of employment disputes).

32. See Paladino, 134 F.3d at 1057.

33. Id. To the same effect is the arbitration agreement struck down in Alexander $v$. Anthony Int'l, L.P., 341 F.3d 256 (3d. Cir. 2003). The employer had imposed an arbitration agreement requiring arbitration of all possible employment-related claims plaintiff might have brought, but limited the arbitrator's authority to grant relief to reinstatement or "net pecuniary damages," which was defined essentially as backpay to the time of the arbitration award. Id. at 260. 
In Mastrobuono $v$. Shearson Lehman Hutton, Inc., ${ }^{34}$ the defendant brokerage house sought to use background law to supply a contract term that would deprive its customers of their punitive damages remedy for securities fraud claims. ${ }^{35}$ The defendant added to its adhesive arbitration clause a provision that incorporated New York decisional law, under which arbitrators had no authority to award punitive damages. ${ }^{36}$ Although limiting issues to be submitted to an arbitrator and waiving substantive rights may be two different matters entirely, the defendant intended to weld the two together, arguing to the Court that "the parties to a contract may lawfully agree to limit the issues to be arbitrated by waiving any claim for punitive damages." 37 The arbitrator did award punitive damages to the Mastrobuonos- $\$ 400,000-$ and defendant Shearson went to court to vacate that part of the award. The United States Supreme Court affirmed the punitive damage award. Although it noted that punitive damages are "an important substantive right," the Court did not decide whether a prospective waiver of that right in an arbitration clause would be enforceable. ${ }^{38}$ Instead the court relied on a contractual ambiguity to construe the agreement to permit the arbitrator to award punitive damages. ${ }^{39}$

Remedy-stripping provisions have not only sought to limit damages, but also attorneys' fees, equitable relief, and the length of statutes of limitations periods. ${ }^{40}$ The latter has been properly viewed as a remedy-stripping clause on the ground that a foreshortened limitations period can itself eliminate a plaintiff's ability to obtain any remedies. A limitations period allows a plaintiff to reflect on whether his rights have been violated and to pursue legal recourse, to seek legal representation, and to conduct-or to give potential attorneys time to conduct-prelitigation investigation into the claims. A shortened limitations period tends to discourage the filing of a claim, and thus has a

34. 514 U.S. 52 (1995).

35. See id. at 59 .

36. See Garrity v. Lyle Stuart, Inc., 353 N.E.2d 793 (N.Y. 1976).

37. Mastrobuono, 514 U.S. at 58.

38. See id. at 63.

39. See id. at 62 .

40. See, e.g., Alexander v. Anthony Int'l, L.P., 341 F.3d 256 (3d Cir. 2003) (precluding equitable relief and prevailing party attorneys' fees, and shortening statute of limitations to 30 days); Stirlen v. Supercuts, 60 Cal. Rptr. 2d 138, 142-43 (Ct. App. 1997) (precluding equitable relief, implicitly barring statutory fee-shifting, and shortening statute of limitations to six months); Graham Oil Co. v. ARCO Prods. Co., 42 F.3d 1244, 1250 (9th Cir. 1994). 
general tendency ex ante to depress the overall value of plaintiffs' claims. ${ }^{41}$

Finally, numerous arbitration agreements contain provisions that bar class actions. In Ting $v$. ATE $T{ }^{42}$ a case involving federal and state law consumer protection claims; the defendant sought to compel arbitration and prevent the maintenance of a class action against it, relying on the following arbitration clause:

This section provides for resolution of disputes through final and binding arbitration before a neutral arbitrator instead of in a court by a judge or jury or through a class action. You continue to have certain rights to obtain relief from a federal or state regulatory agency.

No dispute may be joined with another lawsuit, or in an arbitration with a dispute of any other person, or resolved 'on a class-wide basis. ${ }^{43}$

Other corporate defendants have argued that arbitration clauses bar class actions even without such express exclusionary language; the argument is that arbitrations are by nature individual proceedings, and absent express authorization, the arbitrator exceeds his authority by joining claims or handling a class arbitration. ${ }^{44}$

As a number of courts have recognized, a class action banwhatever the contract language that creates it-is plainly a remedystripping provision. ${ }^{45}$ It is well known that " $[t]$ he policy at the very core of the class action mechanism is to overcome the problem that small recoveries do not provide the incentive for any individual to bring a solo action prosecuting his or her rights." 46 Therefore, barring a class action in some circumstances operates as an exculpatory clause, effectively rendering many small-stakes claims unfeasible. There is no doubt that such is the intent of the drafters of class action bans. ${ }^{47}$

41. Cf. Schwartz, supra note 8 , at 115 (prospective waivers make misconduct less costly by lessening overall liability).

42. 319 F.3d 1126 (9th Cir. 2003).

43. Id. at 1133 n.4. The court ultimately concluded that the class action ban was unconscionable. $I d$. at 1150.

44. This position was argued to the Supreme Court, and adopted by the dissenters, in Green Tree Financial Corp. v. Bazzle, 123 S. Ct. 2402, 2410-11 (2003) (Rehnquist, C.J., dissenting).

45. See, e.g., Ingle v. Circuit City Stores, Inc., 328 F.3d 1165, 1175-76 (9th Cir. 2003); Ting, 319 F.3d at 1150; W. Va. ex. rel. Dunlap v. Berger, 567 S.E.2d 265, 279-80 (W. Va. 2002), cert. denied, 537 U.S. 1087 (2002).

46. Amchem Prods. v. Windsor, 521 U.S. 591, 617 (1997) (internal quotations omitted); see Jean R. Sternlight, As Mandatory Binding Arbitration Meets the Class Action, Will the Class Action Survive?, 42 WM. \& MARY L. Rev. 1, 28-33 (2000).

47. For instance, Alan S. Kaplinsky, a leading arbitration proponent and attorney representing financial services institutions, has been quoted as writing that "Arbitration is a 
[Vol. 38

\section{The Missing Link: Remedy-Stripping and Preclusion Effects}

It is easy to see that remedy-stripping arbitration provisions would have to be given preclusive effect if they are to be fully effective in stripping remedies. Without claim or issue preclusion, the non-drafting party could simply bring his claims to court after the arbitration, and relitigate them from scratch. While arbitration awards are generally accorded preclusive effect (with the important exception of arbitration under a collective bargaining agreement), general principles of res judicata and collateral estoppel significantly restrict the preclusive effect of prior proceedings that excluded the claims or remedies the party subsequently seeks to litigate. Thus, an appreciation of these preclusion principles is essential to a complete understanding of remedy-stripping clauses.

\section{General Principles of Preclusion}

The doctrine of res judicata (also known as "claim preclusion") bars a party to a prior suit from relitigating, in a subsequent suit, any claim or cause of action that was asserted in the prior proceeding. ${ }^{48}$ The modern "transactional" approach holds that res judicata will bar the subsequent assertion of any legal theories or claims that arise out of a litigated transaction or occurrence; a claim that could have been brought in the prior proceeding will be barred to the same extent as those claims actually litigated. ${ }^{49}$ Res judicata is an affirmative defense, which must be pleaded-it is not a jurisdictional matter that need be raised sua sponte by the court-and the party asserting it has the burden of proving that: (1) there has been a final judgment on the merits in the prior proceeding; (2) the second proceeding is based upon the same claim; and (3) the second proceeding is between the same parties or persons in privity with them. ${ }^{50}$

powerful deterrent to class-action lawsuits against lenders . . . Stripped of the threat of a class action, plaintiffs' lawyers have much less incentive to sue." Paul Wenske, Some Cardholders are Signing Away Their Right to Sue, Kan. CiTY StAR, April, 3, 2000, available at http:// www.kcstar.com/projects/carddebt/2side.htm (last accessed Oct. 27, 2003).

48. See, e.g., Val-U Constr. Co. v. Rosebud Sioux Tribe, 146 F.3d 573, 581 (8th Cir. 1998); Wolf v. Gruntal \& Co., 45 F.3d 524, 527 (1st Cir. 1995); Restatement (SEcond) of JUDGMENTS $\$ 27$ (1982).

49. See, e.g., Wolf, 45 F.3d at 527; Restatement (Second) of Judgments $\$ 24$. This concept is sometimes expressed in the doctrines of "merger" and "bar." When the plaintiff obtains a favorable judgment, unasserted claims that could have been brought are "merged" in the judgment; when the defendant wins, the plaintiff's unasserted claims are "barred." See, e.g., Cooper v. Fed. Reserve Bank, 467 U.S. 867, 874 (1984).

50. See, e.g., Wolf, 45 F.3d at 527-28; Restatement (SeCONd) of Judgments $§ 74$; Shell, supra note 6 , at 639-40. 
Collateral estoppel (also known as "issue preclusion") holds that an issue of law or fact litigated between two parties in a prior proceeding cannot be relitigated in a subsequent proceeding if four conditions are met: (1) the identical issue was raised in a previous proceeding; (2) the party against whom collateral estoppel is asserted is the same party, or in privity with, the party in the prior proceeding; (3) the issue was actually litigated to decision and necessary to support a valid and final judgment on the merits in the previous proceeding; and (4) the party had a full and fair opportunity to litigate the issue..$^{51}$ The party asserting collateral estoppel has the burden to establish these four factors. ${ }^{52}$ In contrast to res judicata, which is always a defense, collateral estoppel can be asserted either "defensively" against a plaintiff or "offensively" against a defendant. "Defcnsive" collateral estoppel in effect bars a claim that could not have been asserted in the prior proceeding - and is thus not barred by res judicata-if a factual determination that is a necessary part of the new claim was decided adversely in the prior proceeding. ${ }^{53}$ "Offensive" collateral estoppel works in the converse manner-the "estopped" defendant cannot contest a previously resolved issue that may give rise to liability. ${ }^{54}$

The policies underlying the doctrines of res judicata and collateral estoppel both involve respect for coordinate adjudicative tribunals as well as an efficiency interest in the finality of the prior proceedings. The emphasis of the two doctrines differs somewhat: res judicata "focuses on the general interest in the finality and repose of judgments," whereas collateral estoppel "emphasizes finality of specific instances of factfinding." ${ }^{55}$

These broad principles of res judicata and collateral estoppel are applied, with slight variation, in all American jurisdictions. The general choice of law rule is that a state court must give a judgment whatever preclusive effect (res judicata or collateral estoppel) it would be given by the jurisdiction rendering the judgment. ${ }^{56}$ Federal courts sitting in diversity are supposed to apply the preclusion rules of the forum state, ${ }^{57}$ and, under 28 U.S.C. section 1738 , a federal court is

51. See, e.g., Boguslavsky v. Kaplan, 159 F.3d 715, 719-20 (2d Cir. 1998); Restatement (SECOND) OF JUdGMENTs $\$ 27$; Shell, supra note 6 , at 647-48.

52. See Postlewaite v. McGraw-Hill, Inc., 333 F.3d 42, 49 (2d Cir. 2003).

53. See, e.g., Parklane Hosiery Co. v. Shore, 439 U.S. 322, 329-30 (1979).

54. See id.

55. Shell, supra note 6 , at 648 .

56. 28 U.S.C. $\S 1738$ (2001).

57. See Baker v. Gen. Motors Corp., 522 U.S. 222, 233-34 (1988); Restatement (SeCOND) OF Conflicts of Laws $\S 97$ (1971). 
likewise supposed to give state court judgments the preclusive effect they would get in the courts of that state. ${ }^{58}$

Generally speaking, arbitration awards are given the same preclusive effects as judgments. When an arbitration award is confirmed as a judgment pursuant to the FAA or a state arbitration statute, it is treated the same as any other judgment for res judicata and collateral estoppel purposes. ${ }^{59}$ Unconfirmed arbitration awards are not considered judgments for purposes of 28 U.S.C. section $1738,{ }^{60}$ but most jurisdictions, as a matter of common law, nevertheless treat them as final judgments on the merits for res judicata and collateral estoppel purposes. ${ }^{61}$

This general rule makes sense, in light of the purposes of arbitration and the provisions of the FAA and similar state arbitration laws. Arbitration is normally supposed to be final and binding, and under the FAA and most state arbitration laws, judicial review is narrowly confined. ${ }^{62}$ To fail to give preclusive effect to arbitration awards would undermine the finality of arbitration, while creating a significant loophole in the limited judicial review provisions of the arbitration statutes; courts that could freely relitigate claims decided in arbitration would, in effect, give plenary review to arbitration decisions. But as seen below, all bets are off when claims or remedies are withheld from the arbitrator.

58. See Kremer v. Chemical Constr. Corp., 456 U.S. 461 (1982).

59. See Shell, supra note 6, at 642. Cf. Kremer, 456 U.S. at 485 (holding that administrative decision, confirmed by reviewing court, is judgment entitled to full faith and credit under 28 U.S.C. $\$ 1738$ ). For the procedure to confirm an arbitration award as a judgment, see FAA $\$ 9$, 9 U.S.C. $\$ 9$ (2001).

60. See McDonald v. City of W. Branch, 466 U.S. 284 (1984).

61. See, e.g., Val-U Constr. Co. v. Rosebud Sioux Tribe, 146 F.3d 573, 581 (8th Cir. 1998); Jacobson v. Fireman's Fund Ins. Co., 111 F.3d 261, 266-68 (2d Cir. 1997). The award, though unconfirmed by a court, must be final under the applicable arbitration rules. See Shell, supra note 6, at 641-42.

62. The FAA and most state arbitration statutes confine judicial review of arbitration awards to a few extremely narrow grounds. See, e.g., FAA $\$ 10,9$.U.S.C. $\$ 10$ (holding that awards may be vacated if procured by corruption or fraud, if the arbitrator demonstrated bias, committed serious misconduct, or exceeded his contractual powers). It is well-established that arbitration awards are not subject to judicial review for mere errors of law. There is some authority that they may be vacated for "manifest disregard" of the law. See Wilko v. Swan, 346 U.S. 427, 436-37 (1953) (dictum), overmuled on other grounds, Rodriguez de Quijas v. Shearson/American Express Inc., 490 U.S. 477 (1989); Kanuth v. Prescott, Ball \& Turben, Inc., 949 F.2d 1175, 1178 (D.C. Cir. 1991); Todd Shipyards Corp. v. Cunard Line, 943 F.2d 1056, 1060 (9th Cir. 1991). The "manifest disregard" standard is extremely narrow: only if it is clear from the face of the record that the arbitrator "recognized the applicable law - and then ignored it" will the award be vacated, whereas the award will be upheld if the arbitrator "even arguably" applied the applicable law. Advest, Inc. v. McCarthy, 914 F.2d 6, 9 (1st Cir. 1990). 
There is an established, important exception to the general rule that arbitration awards have full preclusive effect. Arbitrations held pursuant to collective bargaining agreements do not preclude subsequent litigation of federal statutory claims. In Alexander v. Gardner-Denver Co., ${ }^{63}$ the Supreme Court held that the right to a judicial forum for Title VII claims could not be waived by a pre-dispute arbitration clause; and, as a corollary principle, an arbitration pursuant to a predispute agreement would not preclude subsequent litigation of the Title VII claim. ${ }^{64}$ The Court subsequently extended these holdings to Fair Labor Standards Act claims and section 1983 claims, also clarifying that a prior arbitration would have neither res judicata nor collateral estoppel effect on the subsequent federal litigation. ${ }^{65}$ Although all three of these cases involved arbitration pursuant to collective bargaining agreements, most lower courts assumed that the principle applied to "commercial" arbitration clauses as well-private arbitration contracts outside the collective bargaining setting. ${ }^{66}$ The Gardner-Denver line of cases seemed to be based, at least in part, on a view that private arbitration-commercial or collective-offered insufficient judicial quality for the resolution of claims under federal civil rights statutes. That aspect of Gardner-Denver and its progeny is no longer good law, since the Court held in its 1991 decision in Gilmer v. Interstate/ Johnson Lane Corp. ${ }^{67}$ that a pre-dispute arbitration agreement was effective to compel arbitration of federal age discrimination claims. ${ }^{68}$

Gilmer did not overrule the Gardner-Denver line of cases, but rather distinguished it and thereby confined it to collective bargaining agreements, where the waiver by a union of its members' right to go to court on federal civil rights claims is deemed problematic. ${ }^{69}$ GardnerDenver and its progeny continue to control the question of the preclusive effect of a grievance arbitration pursuant to a collective bargain-

63. 415 U.S. 36 (1974).

64. See id. at 51 .

65. See Barrentine v. Arkansas-Best Freight Sys. Inc., 450 U.S. 728 (1981) (holding that FLSA claim is not barred by prior grievance arbitration of same issue); McDonald v. City of W. Branch, 466 U.S. 284 (1984) (holding that unappealed arbitration award did not collaterally estop plaintiff from raising same issue of wrongful discharge in subsequent litigation pursuant to 42 U.S.C. $\$ 1983$ (2001)).

66. See Duffield v. Robertson Stephens \& Co., 144 F.3d 1182, 1188 (9th Cir. 1998); Schwartz, supra note 8, at 93-94.

67. 500 U.S. 20 (1991).

68. See id. at 36-37.

69. See Wright v. Universal Mar. Servs., 525 U.S. 70, 77 (1998); Gilmer, 500 U.S. at 25-26. 
ing agreement on a subsequent civil rights claim. ${ }^{70}$ Such arbitral decisions are accorded neither res judicata nor collateral estoppel effect in the subsequent litigation, irrespective of whether the arbitrator was authorized to consider discrimination issues. ${ }^{71}$ The arbitration award may, at most, be admitted as evidence in the subsequent litigation, at the trial court's discretion. ${ }^{72}$

\section{Preclusion and Non-arbitrable Claims}

Res judicata and collateral estoppel problems arise where a plaintiff asserts arbitrable and non-arbitrable issues arising out of the same transaction. In most cases where a plaintiff brings a case in a state court of general jurisdiction, or in a federal court, the plaintiff can potentially have all of her claims heard and obtain any relief that the law allows. But res judicata is not proper if the forum that rendered the prior judgment lacked jurisdiction to adjudicate the claims and afford complete relief. This principle has been developed in the context of judgments from courts of limited jurisdiction and administrative tribunals. ${ }^{73}$

The same principle applies in the analogous context of arbitration. The general law of arbitrability appears to allow arbitrators to hear virtually any substantive claim and to grant arbitrators the power to award most kinds of relief available in courts. ${ }^{74}$ But arbitration is a

70. See, e.g., Pryner v. Tractor Supply Co., 109 F.3d 354, 365 (7th Cir. 1997).

71. See, e.g., Kennedy v. Superior Printing Co., 215 F.3d 650 (6th Cir. 2000); see also Wright, 525 U.S. 70 (leaving open the question of continuing vitality of Gardner-Denver and holding that, in any event, a collective bargaining agreement cannot be construed as waiving individual members' rights under antidiscrimination statutes absent "clear and unmistakable" language).

72. See, e.g., McDonald v. City of W. Branch, 466 U.S. 284, 292 n.13 (1984) ("an arbitral decision may be admitted as evidence in a $\$ 1983$ action"); Costa v. Desert Palace, Inc., 299 F.3d 838, 863 (9th Cir. 2002), aff'd on other grounds sub nom. Desert Palace, Inc. v. Costa, 123 S. Ct. 2148 (2003); Jackson v. Bunge Corp., 40 F.3d 239 (7th Cir. 1994). Why evidence of an arbitrator's opinion of the dispute would be helpful to a subsequent fact finder has not been explained.

73. See, e.g., Hachanovitch v. Debuono, 159 F.3d 687, 695 (2d Cir. 1998); Colon v. Coughlin, 58 F.3d 865, 870 n.3 (2d Cir. 1995).

74. It seems to be unsettled whether arbitrators can award relief extending beyond the immediate parties to the arbitration agreement, in the form of class actions or injunctions affecting third party rights. See, e.g., Champ v. Siegel Trading Co., 55 F.3d 269, 275 (7th Cir. 1995) (holding that class-action arbitration was barred where the arbitration agreement did not expressly provide for such a procedure); Gov't of U.K. v. Boeing Co., 998 F.2d 68, 74 (2d Cir. 1993) (holding that arbitrator cannot consolidate arbitration proceedings absent the parties' agreement); Cruz v. PacifiCare Health Sys., 66 P.3d 1157 (Cal. 2003) (holding that injunction to protect general public cannot be issued by arbitrator irrespective of terms of arbitration clause). 
matter of contract and "parties are generally free to structure their arbitration agreements as they see fit." 75 Therefore, the arbitration agreement can limit the arbitrator's remedial powers, and the scope of arbitrable issues, to something less than the law of arbitrability would otherwise allow. ${ }^{76}$ Thus, where a party has claims that are not asserted in arbitration because they do not fall within the scope of the arbitration agreement, there can be no preclusion by res judicata of the excluded claims in subsequent litigation. ${ }^{77}$ Moreover, res judicata should be inapplicable even where the arbitrator has arguably been given authority to hear a claim if he has been denied authority to afford full relief. ${ }^{78}$ Such an arbitral decision would not meet the test of a final judgment, and it would be inconsistent with the Supreme Court's guarantee that claims are arbitrable insofar as a party does not "forgo . . . substantive rights."

Collateral estoppel frequently comes up in situations where res judicata is inappropriate: a factual issue may be common to a former and subsequent proceeding, justifying issue preclusion, even though a party may have been unable to raise the same claim in the former proceeding, thereby defeating an assertion of claim preclusion. Since courts have tended to give collateral estoppel effect to arbitrations, there is every reason to suppose that courts would and should apply collateral estoppel principles in cases where the arbitration clause expressly makes some claims arbitrable and others not. ${ }^{80}$ However, whether collateral estoppel should apply where remedy-stripping provisions render certain claims non-arbitrable, or whether an arbitration agreement can be structured to authorize the arbitrator to issue preclusive findings on liability when not authorized to award complete relief, are somewhat different questions. I address them below. ${ }^{81}$

75. Volt Info. Scis., Inc. v. Bd. of Trs., 489 U.S. 468, 479 (1989).

76. See id. (parties "may limit by contract the issues which they will arbitrate").

77. See, e.g., Wolf v. Gruntal \& Co., 45 F.3d 524, 527 (1st Cir. 1995) ("Res judicata is not implicated if the forum which rendered the prior 'judgment' (viz., the arbitral award) lacked 'jurisdiction' over the putatively precluded claim (viz, the Rule $10 \mathrm{~b}-5 \mathrm{claim}$ ).").

78. See Blumenthal v. Merrill Lynch, Pierce, Fenner \& Smith, Inc., 910 F.2d 1049, 1055 (2d Cir. 1990) ("we are not obligated to give res judicata effect to arbitration proceedings, especially where it is unclear whether the arbitrators here would have been able to grant relief . . . as sought by the plaintiffs in federal court").

79. Gilmer v. Interstate/Johnson Lane Corp., 500 U.S. 20, 26 (1991) (quoting Mitsubishi Motors Corp. v. Soler Chrysler-Plymouth, Inc., 473 U.S. 614, 628 (1985)), quoted in Circuit City Stores v. Adams, 532 U.S. 105, 123 (2001).

80. See, e.g., Boguslavsky v. Kaplan, 159 F.3d 715, 720 (2d Cir. 1998).

81. See discussion infra Part IV. 


\section{Three Judicial Approaches to Non-Enforcement of Remedy-Stripping Clauses}

Courts have had no trouble concluding that remedy-stripping provisions in adhesion contracts cannot be enforced in a manner that would deprive the plaintiff of substantive rights. ${ }^{82}$ But the question of whether and how an arbitration should go forward under a remedystripping clause has led to three divergent approaches. The first two approaches are typically presented to courts as a single pair of alternatives, turning on the question of validity. The arbitration agreement is treated as a whole: the court can either deny enforcement to the arbitration agreement in toto or remake the agreement into one that is fully enforceable by "severing" the offending terms. The third approach treats the remedy limitation as raising a question of arbitrability: should certain issues be excluded from arbitration to conform to the arbitrator's limited remedial authority? While all three approaches correctly refuse to apply the clause to effect a waiver of substantive rights and remedies, I argue that holding the entire arbitration clause invalid is the best approach, since it best deters the drafting of overreaching arbitration provisions.

\section{A. Validity: Reject the Entire Arbitration Agreement or Sever the Offending Terms}

A number of cases have concluded that remedy-stripping provisions render an arbitration clause unconscionable, and therefore unenforceable in its entirety. The question typically presented to the court is whether the unlawful remedy-stripping provisions are "severable" from the rest of the arbitration agreement. In Stirlen, for instance, the defendant argued that "severing"-in, essence, deleting the offending remedy limitations-would leave an enforceable agreement, one that simply provided for arbitration of all employment disputes and authorized the arbitrator to award whatever remedies the law allowed. ${ }^{83}$

82. I have found only one case that treated an adhesive remedy-stripping clause as a waiver of a remedy. In Waltman $v$. Fahnestock $\mathcal{E}$ Co., 792 F. Supp. 31, 33-34 (E.D. Pa. 1992), affd, 989 F.2d 490 (3d Cir. 1993), the court held that res judicata barred the plaintiff's assertion of a punitive damages claim subsequent to an arbitration in which the arbitrator lacked authority to award punitive damages. This decision seems plainly wrong, particularly in light of the Supreme Court's subsequent assertion that punitive damages are substantive rights, together with the Court's consistent position that arbitration should not waive substantive rights. See supra notes $20-24$ and accompanying text.

83. See Stirlen v. Supercuts, Inc., 60 Cal. Rptr. $2 d 138$ (Ct. App. 1997). 
Graham Oil Co. v. ARCO Products $\mathrm{Co}^{84}$ is the leading case on the severance issue. ARCO had imposed an adhesion contract on a gas station owner that contained a pre-dispute arbitration clause making arbitration the exclusive remedy for any dispute between the parties and expressly prohibiting the arbitrator from assessing tort and statutory damages. The contract was plainly intended to strip the plaintiff of his rights under the Petroleum Marketing Practices Act. The court denied enforcement of the arbitration clause in its entirety, rather than severing the remedy limitations and compelling arbitration under less unfair terms. The court reasoned that general contract principles hold it improper to sever a contract term from other terms with which it is closely integrated: "[A] contract should be treated as entire when by consideration of its terms, nature and purposes each and all of the parts appear to be interdependent and common to one another." ${ }^{55}$ In Graham Oil, it was plain that the remedy-limiting provisions were intended by the drafter to work in concert with the arbitration requirement to strip the plaintiff's remedies. Moreover, the illegal purpose was itself significant to the severance issue: ARCO was attempting to "achieve through arbitration" an unlawful evasion of substantive regulatory law. Severance is particularly inappropriate "when the entire clause represents an integrated scheme to contravene public policy." 86

The argument for severance has been rejected more often than not, and quite properly so. ${ }^{87}$ The case for severance is necessarily

84. 43 F.3d 1244 (9th Cir. 1994).

85. Id. at 1248 (quoting John D. Calamari \& Joseph M. Perillo, The Law of ConTRACTS 478 n.76 ( 3 d ed. 1987)).

86. Graham Oil, 43 F.3d at 1249 (quoting E. Allan Farnsworth, Farnsworth on ConTraCts $\$ 5.8$, at 70 (2d ed. 1990)).

87. See Armendariz v. Found. Health Psychcare Servs., Inc., 6 P.3d 669 (Cal. 2000); Stirlen, 60 Cal. Rptr. 2d 138; Alexander v. Anthony Int'l, L.P., 34l F.3d 256 (3d. Cir. 2003). A leading case supporting severance of offending terms is Graham v. Scissor-Tail, Inc., 623 P.2d 165 (Cal. 1981), which is more well known, and far more often cited, for its leading analysis of unconscionability, rather than for its severance remedy. In Scissor-Tail, Bill Graham, a prominent rock music promoter, successfully challenged an adhesive contract term requiring arbitration before an arbitrator chosen by his adversary in the dispute, the music technician's union. The court "severed" the arbitrator selection provision and ordered arbitration to proceed pursuant to the state procedural statute, which provided a neutral process for selecting the arbitrator. Significantly, Scissor-Tail involved a discrete procedural unfairness rather than "an 'integrated scheme to contravene public policy.'" Graham Oil, 43 F.3d at 1249 .

A court is more likely to sever where the remedy-stripping is limited to the ancillary remedy of attorneys' fees. A number of cases have held that arbitration agreements that expressly or impliedly provide for each party to bear its own attorneys' fees are inconsistent with fee-shifting statutes that allow prevailing plaintiffs to recover their fees more readily 
based on placing the FAA's purported policy favoring arbitration above any public policy disfavoring attempts to draft contractual loopholes to evade regulatory statutes. But even the pro-arbitration policy is questionable in the remedy-stripping context. The policy associated with the FAA is not the achievement of more arbitration per se, but enforcement of the parties' intentions as to arbitration. This policy assumes an enforceable contractual intention and so necessarily begs the question of whether an enforceable agreement exists. By cleaning up a facially unenforceable arbitration provision, the court respects neither the intention of the party challenging the arbitration agreement-who typically wants to litigate rather than arbitrate, but had no say in the matter of the initial adhesion contract-nor the party who drafted it. ${ }^{88}$ The latter's intention was not the sanitized arbitration offered by the courts, but an unfair arbitration with limited remedies. That the drafter, in subsequent litigation, is willing to back away from its more aggressive position and accept the "fair" arbitration as a second best alternative is not a reflection of its intent as expressed objectively in the written contract. ${ }^{89}$

There is a more important reason to deny severance. The remedy limitations in a remedy-stripping arbitration clause are designed to work in tandem with the choice of arbitration to achieve the evasion of substantive liability. The arbitration term is thus truly integrated with the "scheme to contravene public policy." 90 But severance rewrites the contract and gives the drafting party the benefit of the more

than prevailing defendants. See, e.g., Spinetti v. Serv. Corp. Int'l, 324 F.3d 212 (3d Cir. 2003); Cole v. Burns Int'l Sec. Servs., 105 F.3d 1465 (D.C. Cir. 1997). In Spinetti, where the attorneys' fee provision was the main defect, the court reformed the arbitration agreement rather than holding it unenforceable. See Spinetti, 324 F.3d at 220-21.

88. As Professor Stephen Ware points out, the "wishes" or intent of the parties that matters in pre-dispute arbitration agreements under the FAA is the intent reflected in the contract, as opposed to the parties' respective wishes in making or opposing a motion to compel arbitration. See, e.g., Stephen J. Ware, Employment Arbitration and Voluntary Consent, 25 Hofstra L. Rev. 83, 107-08 (1996). With remedy-stripping agreements, the drafter's intent is plainly to affect a prospective waiver, see infra text accompanying notes 108-09, 195-96, an intent that is uniformly held to be unenforceable. Courts that try to rewrite such flawed arbitration agreements to save something to be arbitrated have plainly departed from the parties' intent manifested in the contract. Moreover, in the present context, it is a mistake to ignore the actual desires of the parties with respect to arbitration: those are highly relevant to determining the deterrent effects of the various approaches on overreaching drafters.

89. See Stirlen, 60 Cal. Rptr. 2d 138. As the court said in Armendariz, remedy-stripping terms "indicate a systematic effort to impose arbitration on an employee not simply as an alternative to litigation, but as an inferior forum that works to the employer's advantage." Armendariz, 6 P.3d at 697.

90. Graham Oil, 43 F.3d at 1249. 
reasonable contract it should have written, but didn't. A party seeking to obtain unlawful advantages through contract should not be handed its second best alternative by judicial blue-penciling. Such an approach unduly encourages the use of overreaching arbitration clauses; the drafter, knowing it will get arbitration at a minimum, can try to improve its position with no risk by adding remedy-stripping terms. And who knows? Maybe an errant court will enforce the remedy-stripping clause; maybe the plaintiff will accept the remedy-stripping clause without challenge, or even let the clause deter him from pursuing his rights at all. Overreaching clauses in adhesion contracts can work harms by being passed off in transactions, even if they are ultimately unenforceable when legally tested, because they will not be legally tested in every instance. Some sanction seems appropriate to discourage them; striking an arbitration agreement in its entirety is a reasonable deterrent to the drafting of illegal remedy-stripping clauses. "An employer will not be deterred from routinely inserting such a deliberately illegal clause into the arbitration agreements it mandates for its employees if it knows that the worst penalty for such illegality is the severance of the clause after the employee has litigated the matter."91

91. Armendariz, 6 P.3d at 697 n.13. Some courts have essentially rewritten arbitration agreements in a more ambitious manner than by severing offending terms, though in the somewhat different context of unfair or inadequate arbitration procedures. Although the courts have been extremely hostile to "generalized attacks" on the adequacy of arbitration procedures as a basis to invalidate a pre-dispute arbitration clause, see, e.g., Gilmer v. Interstate/Johnson Lane Corp., 500 U.S. 20, 33 (1991), the Supreme Court in Gilmer expressly left open the possibility that claims of "procedural inadequacies" of arbitration under the terms of a specific arbitration agreement may be "resolv[ed] in specific cases." Id. Taking up this matter, the court in Cole v. Burns International Security Services, 105 F.3d 1465 (D.C. Cir. 1997), held that a standard arbitration clause unadorned by any remedy-stripping terms was inadequate for resolution of Title VII claims. The remedy imposed by the court was to write into the arbitration clause a set of minimal procedural standards that courts would require to compel arbitration of statutory civil rights claims. According to the Cole opinion, "Gilmer cannot be read as holding that an arbitration agreement is enforceable no matter what rights it waives or what burdens it imposes," and an enforceable compelledarbitration agreement should provide at a minimum for: (1) a neutral arbitrator; (2) more than minimal discovery; (3) a written award; (4) full statutory remedies that would otherwise be available in court; and (5) no burden on the employee to pay either unreasonable costs or any arbitrators' fees or expenses. Id. at 1482.

It is unclear from Cole whether the remedy would always be to rewrite the arbitration agreement, or whether denial of enforcement would be appropriate where the arbitration agreement actually spelled out unfair terms. In Armendariz, the California Supreme Court, relying heavily on Cole, determined that the remedy would be to void the arbitration agreement where key elements of procedural unfairness were present, combined with substantive remedy-stripping and lack of mutuality of the agreement. Where procedural unfairness is egregious enough, some courts will deny enforcement rather than rewrite the agree- 


\section{B. Arbitrability: Narrow the Scope of Arbitrable Issues}

A number of courts have approached remedy-stripping clauses as questions of "issue-arbitrability," 92 using the remedy-stripping clause to define and narrow the scope of arbitrable issues while compelling some claims to go forward in arbitration. A leading case is Paladino, ${ }^{93}$ where the court reviewed a motion to compel arbitration under a clause in which the arbitrator was authorized "to award damages for breach of contract only, and shall have no authority whatsoever to make an award of other damages." 94 The plaintiff sued for discrimination and wrongful discharge under Title VII, and state statutory and common law. The employer conceded that the damages limitation was illegal and made the severance argument, urging the court to enforce the arbitration clause with an interpretation allowing the arbitrator to award all damages authorized by law. The court rejected that argument, holding that only contract claims could go forward in arbitration and denying arbitration for the other claims. ${ }^{95}$ The judges divided on the rationale. All three judges understood the broad arbitrability clause to apply to extra-contractual claims, including the Title VII claims. ${ }^{96}$ But Judges Cox and Tjoflat held that the arbitration agreement was unenforceable as to Title VII claims, reasoning that the remedy limitation "defeats the statute's remedial purposes because it insulates Avnet from Title VII damages and equitable relief."97 Judge Hatchett, in contrast, concluded that the clause was ambiguous rather than unenforceable. The remedy limitation could be understood as a

ment. Armendariz, 6 P.3d at 695-99. In Hooters of America, Inc. v. Phillips., 173 F.3d 933 (4th Cir. 1999), the Hooters restaurant chain forced its employees, as a condition of employment, to agree to an arbitration scheme containing several "egregiously unfair" rules. The employee, at the time she demanded arbitration, was required to provide the employer with a statement of the nature of the claim, factual summary, and witness list, whereas the employer did not have to provide any notification of its defenses or witnesses. The employer had the right to move for summary judgment in the arbitration and to seek full judicial review of an award; the employee had no such rights. And the panel of three arbitrators was to be drawn from a list of arbitrators created exclusively by Hooters, giving the employer unlimited control over the composition of the panel. The court he'd that "the promulgation of so many biased rules" created "a sham system unworthy even of the name of arbitration," thereby constituting a breach of the arbitration agreement by Hooters, for which the employee's remedy was rescission of the arbitration agreement. Id. at 939-40.

92. See infra text accompanying notes 149-50.

93. See supra text accompanying notes 29-33.

94. Paladino v. Avnet Computer Techs., 134 F.3d 1054, 1061 (11th Cir. 1998).

95. See id. at 1060.

96. See id. at 1059-60; see supra text accompanying notes 29-33.

97. Paladino, 134 F.3d at 1062 (Cox, J., concurring). 
limitation, not on the arbitrator's remedial authority, but on the issues to be submitted to arbitration. ${ }^{98}$ The remedy limitation, according to Judge Hatchett, thus conflicted with the all-inclusive arbitrability clause, creating an ambiguity that allowed the court leeway to decide as a matter of interpretation that the arbitration clause objectively intended to cover only contract disputes, and not the Title VII and other non-contract claims. ${ }^{99}$ The difference in reasoning between the two Paladino opinions did not make a difference to the result. Either way, the court would determine that the non-contract claims were not arbitrable, but that arbitration could proceed on the contract claims.

This arbitrability approach to remedy-stripping clauses also finds support in two recent cases from the California Supreme Court, deciding that statutory "public policy" claims could not be compelled into arbitration. In Broughton v. Cigna Healthplans, ${ }^{100}$ the court held that claims for injunctive relief under the state Consumer Legal Remedies Act designed to protect the public from deceptive business practices were not subject to arbitration. ${ }^{101}$ In Cruz v. PacifiCare Health Systems, ${ }^{102}$ the court extended that holding to preserve claims to enjoin unfair competition and misleading advertising under the state Business and Professions Code. ${ }^{103}$ According to the Broughton and Cruz courts, such claims were unsuitable for arbitration because (1) these statutory injunction claims were "for the benefit of the general public rather than the party bringing the action," and (2) courts have "significant institutional advantages over arbitration in administering a public injunctive remedy, which as a consequence will likely lead to the diminution or frustration of the public benefit if the remedy is entrusted to arbitrators." 104 For these reasons, the court concluded there was an inherent conflict between arbitration and the statutory reme-

98. See id. at 1058. For some reason, the opinion is announced in the manner of seriatim opinions of old-none is designated the opinion of the Court, and the Cox-Tjoflat opinion is called a concurring opinion.

99. See id. at 1057, 1059-60. For similar treatment of the same arbitration agreement, see Alcaraz $v$. Avnet, Inc., 933 F. Supp. 1025 (D.N.M. 1996). Judge Hatchett thus dodged the enforceability question, much as the Supreme Court did in Mastrobuono v. Shearson Lehman Hutton, Inc., 514 U.S. 52 (1995). See supra text accompanying notes 38-39.

100. 988 P.2d 67 (Cal. 1999).

101. See id. at 79 .

102. 66 P.3d 1157 (Cal. 2003).

103. See id. at 1165 .

104. Id. at 1162 (quoting Broughton, 988 P.2d at 78). 
dies, which gave rise to the inference that the state legislature intended to withhold the substantive claims from arbitration. ${ }^{105}$

105. On a separate point, the California court's reasoning raises questions about preemption that are beyond the scope of this article. How can a state legislature decide to withhold a public injunction claim from arbitration when Southland Corp. v. Keating, 465 U.S. 1, 10 (1984) and Perry v. Thomas, 482 U.S. 483, 489 (1987) held that the FAA "withdrew the power of the states to require a judicial forum for the resolution of claims which the contracting parties agreed to resolve by arbitration"? The California court's answer to that question is to assert that state legislatures have the same power that Congress does to make certain kinds of claims non-arbitrable, either expressly or by implication, by creating a right or remedy having an "inherent conflict" with arbitration. See Cruz, 66 P.3d at 1162-63; Broughton, 988 P.2d at 72 (citing Shearson/American Express Inc. v. McMahon, 482 U.S. 220 (1987)). But doesn't the Supremacy Clause suggest that Congress and state legislatures are not on equal footing when it comes to creating exceptions to a federal statute? On closer inspection, Cruz and Broughton have the better of the argument. To begin with, as the California court is quite correct in pointing out, the United States Supreme Court "has never directly decided whether a [state] legislature may restrict a private arbitration agreement when it inherently conflicts with a public statutory purpose that transcends private interests." Cruz, 66 P.2d at 1163 (quoting Broughton, 988 P.2d at 78-79). All of the FAA preemption cases decided by the United States Supreme Court, to date, have involved private damages claims, not public injunctions, so the Court has never had occasion to determine whether broad injunctive relief affecting third parties or the public can be issued by arbitrators. What the Court has said, however, is that compelled arbitration of statutory claims is appropriate insofar as the claimant "does not forgo ... substantive rights[.]” E.g., Gilmer v. Interstate/Johnson Lane Corp., 500 U.S. 20, 26 (1991) (quoting Mitsubishi Motors Corp. v. Soler Chrysler-Plymouth, Inc., 473 U.S. 614, 628 (1985)), quoted in Circuit City Stores v. Adams, 532 U.S. 105, 123 (2001). Absent an express guarantee by the Supreme Court that arbitrators can issue and administer public injunctions, a state court is free to reach the common-sense, highly practical conclusion that arbitrators cannot do so. This the California courts have done. In such a case, compelling public injunction claims into arbitration would indeed "forgo substantive rights."

Broughton and Cruz exemplify, moreover, the best approach of a state court to the federalism issues surrounding FAA preemption. The California court's correct conclusion that the FAA has not authoritatively been held to encompass public injunction claims is significant, because under the Tenth Amendment to the United States Constitution, states retain by default all powers not removed from them, either by constitutional provisions or by statutory preemption under the Supremacy Clause. U.S. Consr. amend. X ("The powers not delegated to the United States by the Constitution, nor prohibited by it to the States, are reserved to the States respectively, or to the people."). By refusing to extend the FAA to a new area-public injunction rather than private damages claims-the court (albeit without explicitly acknowledging this) properly applied the federalism-based presumption against preemption and doctrine of constitutional avoidance. The presumption against preemption should work against any extension of the FAA into a new area, in the absence of a clear statement from Congress of an intent to upset the normal federal-state balance. Here, a state's power to administer its own dispute resolution system and to allocate certain substantive state claims to specific state remedial and procedural structures would be undermined by extension of FAA preemption. Similarly, this aspect of Southland-dictating intrastate dispute resolution mechanisms for state law claims-is the most constitutionally dubious application of FAA preemption, and by upholding the authority of the state in this case, the California Supreme Court avoided the constitutional issue-an issue that has never expressly been decided by the United States Supreme Court. 
Cruz and Broughton are not contract interpretation cases per se; rather they entail the application of background state law overriding the contract's prima facie choice. The contract did not prohibit the arbitrators from awarding public injunctions; rather, state law did, but that background law became a term of the contract, just like any nonwaivable rule of state contract law. What links Cruz and Broughton to Paladino is the plausible conclusion that the underlying substantive claim can be adjudicated only in a forum that can issue the remedythere is to be no bifurcation of liability and remedy between different fora.

In two respects, the arbitrability approach to remedy-stripping agreements makes sense. First, this arbitrability approach rests on the sensible idea that the remedy is inextricable from the substantive claim: an adjudicative body that cannot give the remedy carried by the substantive law claim does not have complete authority over the subject matter and, therefore, should not be allowed to issue a binding, preclusive decision on substantive liability either. That notion is certainly consistent with the Supreme Court's repeated admonition that pre-dispute arbitration agreements are unproblematic insofar as a party in arbitration "does not forgo ... substantive rights." 106 Second, for the same reason, it is not utterly implausible to say that a remedy limitation expresses an "objective" contractual intent to limit the substantive issues to be submitted to the arbitrator. The arbitrability approach also has a third-in my view, more dubious-implication: compared to holding the clause entirely unenforceable, it better comports with the judicial policy often loosely attributed to the FAA that, in essence, more arbitration is better.

But the arbitrability approach shares the same flaw as the severance approach, though perhaps to a lesser degree: it lets overreaching drafters get away with an attempt to violate public policy. Courts that have reformed remedy-stripping clauses have sometimes relied on the concept that "where a contract is unclear on a point, an interpretation that makes the contract lawful is preferred to one that renders it unlawful." 107 Yet remedy-stripping provisions are really not unclear; their intent, as correctly recognized by some courts, is "an integrated

106. E.g., Gilmer, 500 U.S. at 26 (quoting Mitsubishi, 473 U.S. at 628), quoted in Circuit City, 532 U.S. at 123.

107. Cole v. Burns Int'l Sec. Servs., 105 F.3d 1465, 1485 (D.C. Cir. 1997); Paladino v. Avnet Computer Techs., 134 F.3d 1054, 1058 (11th Cir. 1998). 
scheme to violate public policy." 108 The primary purpose of these clauses is not arbitration, but to immunize the drafter from certain kinds of claims and certain forms of relief. If there is any doubt that the primary purpose is the unlawful, remedy-stripping objective, rather than a more limited arbitration, consider how straightforward it would be to draft the arbitration clauses that courts like Paladino ultimately fashion. The drafter need simply write that only those claims "for breach of contract" or "sounding in contract" shall be submitted to arbitration. Where there is misconduct in the drafting of the contract, the common law's interpretive bias tilts-as it should-heavily against the drafter. ${ }^{109}$ The Paladino approach lets this misconduct off too lightly.

\section{Changing Law? The Impact of the Supreme Court's October 2002 Term Arbitration Trilogy on Remedy- Stripping Clauses}

The Supreme Court decided a trio of arbitration cases in its October 2002 term. All three of them-Howsam v. Dean Witter Reynolds, Inc., ${ }^{110}$ PacifiCare Health Systems, Inc. v. Book, ${ }^{111}$ and Green Tree Financial Corp. v. Bazzle ${ }^{12}$-raise questions that will bear on the judicial treatment of remedy-stripping arbitration clauses. The decisions are somewhat maddening. Book and Bazzle both dodge the big question of whether remedy-stripping provisions (in Book, a damages limitation, in Bazzle, a class action ban) are enforceable, and all three have an abstruse, hypertechnical quality that is likely to sow some confusion among lower courts.

I argue that Howsam, Book, and Bazzle are best understood as limited holdings about whether certain arbitrability decisions are to be determined by a court or an arbitrator. Specifically, arbitrability questions are for the arbitrator to decide only when it has been determined that a valid arbitration agreement exists, and only then when the arbitrability question turns on a contract ambiguity that does not affect the enforceability of the agreement. Questions of the overall validity of the arbitration agreement remain for the court to decide, as

108. Graham Oil Co. v. ARCO Prods. Co., 43 F.3d 1244, 1249 (9th Cir. 1994); accord Armendariz v. Found. Health Psychcare Servs., Inc., 6 P.3d 669 (Cal. 2000).

109. See Restatement (Second) of Contracts $\$ 184$ (1979); Restatement (First) of Contracts $\$ 603$ (1932).

110. 537 U.S. 79 (2002).

111. 123 S. Ct. 1531 (2003).

112. 123 S. Ct. 2402 (2003). 
do questions going to whether an arbitration agreement is enforceable as to a particular type of claim.

\section{A. The 2002-03 Arbitration Trilogy \\ 1. Howsam}

In Howsam, an investor claimed damages against her securities broker for allegedly fraudulent investment advice and petitioned for an arbitration under the arbitration procedures of the National Association of Securities Dealers ("NASD"). ${ }^{13}$ It was undisputed that the parties were bound by a standard securities-industry arbitration agreement specifying the NASD as the arbitration forum. Defendant Dean Witter, however, argued that the arbitration claim was barred by the six year statute of limitations provided under the NASD rules, and sought a judicial determination to that effect and an injunction against any arbitration proceeding. ${ }^{14}$ The question for the Supreme Court was whether a court or an arbitrator should decide whether the arbitration was time barred. ${ }^{115}$

The case seems to have been a simple one made more complex than necessary. It was undisputed that the arbitration agreement was valid, that the NASD rules applied, and that the substantive claim was "arbitrable," in the sense that it presented a subject matter suitable for arbitration. The only question was the application of concededly controlling rules to the facts of the dispute, specifically, whether under the facts-the date on which the dispute arose-the defendant had a dispositive statute of limitations defense. ${ }^{116}$ Plainly, this is a question for the arbitrator, as would be any affirmative defense. Probably because the statute of limitations is a technical (rather than a merits) defense, however, and can be viewed as a threshold question determining whether the arbitration on the merits will go forward, some courts have tripped themselves up by calling the statute of limitations an "arbitrability" question. This in turn would have triggered the rule that questions of arbitrability are for the court to decide unless the arbitration agreement states in "clear and manifest" terms that such questions are for the arbitrator. ${ }^{117}$

113. See Howsam, 537 U.S. at 82.

114. See id.

115. See id. at 83 .

116. See id. at 85 .

117. See First Options of Chi., Inc. v. Kaplan, 514 U.S. 938 (1995); AT\&T Techs., Inc. v. Communications Workers of Am., 475 U.S. 643 (1986). 
The Court sensibly determined that the statute of limitations question was for the arbitrator, and was not a question of "arbitrability." 118 The Court could simply have stated that an arbitrator determines all affirmative defenses in cases involving arbitrable issues and an undisputedly valid arbitration agreement. Instead, the Court made its rationale turn on some overly fine definitional points about "arbitrability." The Court noted some looseness in how the term "arbitrability" is used: the term sounds like it could refer to any legal issue that would determine whether an arbitration on the merits will go forward. ${ }^{119}$ It would have been useful at this point for the court to clear up the meaning of "arbitrability" once and for all, by limiting it to the two traditional arbitrability questions which are presumptively for the court: (1) whether the arbitration agreement covers the parties, and (2) whether the arbitration agreement extends to the substantive issues raised. ${ }^{120}$ Instead, the court calls all of these questions "gateway" disputes over whether the arbitration on the merits will proceed, and in one passage seems to make the inquiry turn on the rather elusive question of whether the "contracting parties would likely have expected a court to have decided the gateway matter," i.e., where they are unlikely to have thought that they had agreed to submit the "gateway matter" to the arbitrator. ${ }^{121}$ Not only is this language a bit more obscure than need be, but it is fanciful in the context of adhesive arbitration clauses-virtually all arbitration clauses in the consumer and employment contexts, where this doctrine will perhaps most often be applied-to talk about the parties' expectations, when one of the parties, is unlikely to have had any expectations or even awareness of the arbitration clause.

\section{Book}

PacifiCare Health Systems, Inc. v. Book arose out of a complex litigation brought by various patient and physician plaintiff groups against health insurers and HMOs for reimbursement and coverage prac-

118. See Howsam, 537 U.S. at 84-85.

119. "Linguistically speaking, one might call any potentially dispositive gateway question a 'question of arbitrability,' for its answer will determine whether the underlying controversy will proceed to arbitration on the merits." Id. at 83.

120. Howsam does identify these two categories of arbitrability, "whether the arbitration contract bound the parties" and "whether an arbitration clause in a concededly binding contract applies to a particular type of controversy," but then fails to drive the point home. Id. at 84.

121. See id. at 83. 
tices. ${ }^{122}$ The physician plaintiffs brought claims under the Racketeer Influenced and Corrupt Organizations Act ("RICO") and various other federal and state statutes and common law theories. The defendants moved to compel arbitration of all claims. The district court held that some of the claims would be ordered into arbitration, but denied arbitration of the RICO claims, on the theory that remedystripping provisions in the arbitration clauses would prevent plaintiffs from "obtain [ing] 'meaningful relief" and were therefore unenforceable under Paladino. ${ }^{123}$ The Eleventh Circuit affirmed, but the United States Supreme Court reversed. ${ }^{124}$

Before the Supreme Court, the parties argued both about "whether the remedial limitations render their arbitration agreements unenforceable" and about who decides that question-the court or the arbitrator. ${ }^{125}$ The Court concluded that it was "premature" to address those questions, owing to ambiguities in the relationship between the remedy-stripping provisions and the right to treble damages in RICO claims:

Two of the four arbitration agreements at issue provide that "punitive damages shall not be awarded [in arbitration],,$\ldots$ one provides that " $\mathrm{t}]$ he arbitrators . . . shall have no authority to award any punitive or exemplary damages," . . . and one provides that "[t]he arbitrators ... shall have no authority to award extra contractual damages of any kind, including punitive or exemplary damages[.]" Respondents insist, and the District Court agreed, that these provisions preclude an arbitrator from awarding treble damages under RICO. We think that neither our precedents nor the ambiguous terms of the contracts make this clear. ${ }^{126}$

According to the Court, treble damages under RICO are compensatory, not punitive; and they may even be considered "contractual" rather than "extra-contractual" damages, if the former were understood as economic and the latter "non-economic" ("such as punitive or mental-anguish damages"). ${ }^{127}$ The Court apparently assumed, arguendo, that a remedy limitation barring treble damages would render the RICO claims non-arbitrable. But the Court asserted that it would not presume that an arbitrator will construe an ambiguous arbitration agreement in a manner that renders the agreement

122. See In re Managed Care Litig., 132 F. Supp. 2d 989 (S.D. Fla. 2000), affd sub nom. In re Humana Inc. Managed Care Litig., 285 F.3d 971 (11 th Cir. 2002), rev'd and remanded sub nom. PacifiCare Health Sys. v. Book, 123 S. Ct. 1531 (2003).

123. Book, 123 S. Ct. at 1534.

124. See id. at 1534-36

125. Id. at 1534 .

126. Id. at 1535 (citations omitted).

127. Id. at $1535 \&$ n. 1 . 
unenforceable. Instead, "the proper course is to compel arbitration" and, presumably, see how the arbitrator actually construes the agreement. ${ }^{128}$

\section{Bazzle}

In Green Tree Financial Corp. v. Bazzle, ${ }^{129}$ two separate consumer class actions (the Bazzle action and the Lackey action) were filed in the state courts of South Carolina against Green Tree Financial Corp., a nationwide consumer loan company. ${ }^{130}$ In each case, Green Tree successfully moved to compel arbitration. ${ }^{131}$ But in Bazzle, the trial court certified a plaintiff class before sending the case to arbitration. ${ }^{132}$ The Lackey action, by agreement of the parties, went to the same arbitrator handling Bazzle, and the arbitrator certified a plaintiff class in that case, too. ${ }^{133}$ The arbitrator ultimately found for the claimants in both class actions, and awarded a total of approximately $\$ 27$ million in damages and attorneys' fees against Green Tree. ${ }^{134}$ The South Carolina Supreme Court rejected Green Tree's challenge to the classwide arbitration procedure, on the ground that class arbitration was permissible as a matter of state procedural law. ${ }^{135}$ In its argument to the United States Supreme Court, Green Tree asserted that an arbitration agreement that does not expressly authorize class arbitrations must be construed as barring class claims entirely, and, under the FAA, be enforced "as written." 136

Wholly apart from the multi-million dollar stakes in Bazzle, the implications of Green Tree's argument for consumer protection law generally are potentially very great. Green Tree argued for nothing less than a federal rule allowing arbitration agreements to exempt the drafter from class actions. ${ }^{137}$ This in itself would be an extraordinary exemption from state consumer contract regulation, since " $t \mathrm{t}]$ he policy at the very core of the class action mechanism is to overcome the

\footnotetext{
128. Id. at 1536 .

129. 123 S. Ct. 2402 (2003).

130. See id. at 2405.

131. See id.

132. See id.

133. See id. at 2406.

134. See id. at 2405-06.

135. See id. at 2406.

136. See id.

137. See id. at 2407-08.
} 
problem that small recoveries do not provide the incentive for any individual to bring a solo action prosecuting his or her rights." 138

Bazzle in the end resolved very little other than the case at hand. A four-justice plurality opinion by Justice Breyer reasoned that the issue of "whether the arbitration contracts forbid class arbitration"139 was a contract-interpretation question for the arbitrator, and not the courts. According to the Bazzle plurality, "gateway" matters for the court to decide include "whether the parties have a valid arbitration agreement at all or whether a concededly binding arbitration clause applies to a certain type of controversy." 140 But questions of "contract interpretation and arbitration procedures" are for the arbitratorhere, whether the arbitration should be a class action was a question of "what kind of arbitration proceeding the parties agreed to." 141 Accordingly, the plurality-joined in the judgment by Justice Stevens-vacated the judgment of the South Carolina Supreme Court, and remanded the case to allow the arbitrator to make this determination. ${ }^{142}$ Bazzle implies that class arbitrations are permissible, but the two opinions forming the judgment do not indicate whether an unambiguous class action ban would be enforceable.

\section{B. Making Sense of Howsam, Book, and Bazzle: The Arbitrability/ Validity Distinction}

\section{Who Decides?}

It is tempting to gloss over the excessive subtlety of Howsam, Book, and Bazzle and identify their holdings in terms of their broad similarities. In all three cases, the Court held that a significant "gateway" issue was to be decided by the arbitrator. In Book and Bazzle, the issue was a purported contractual ambiguity touching on the enforceability of a remedy-stripping provision. Yet the Court did not pass generally on

138. Amchem Prods. v. Windsor, 521 U.S. 591, 617 (1997) (internal quotations omitted); see Sternlight, supra note 46 , at 28-33.

139. Bazzle, 123 S. Ct. at 2407.

140. Id.

141. Id.

142. Although the arbitrator had himself certified a class action in the Lackey action, the Supreme Court observed that he did so only after the trial court had certified a class on the same issues in the Bazzle action. Thus, "[o]n balance, there is at least a strong likelihood in Lackey as well as in Bazzle that the arbitrator's decision reflected a court's interpretation of the contracts rather than an arbitrator's interpretation." Id. at 2408. Nevertheless, it seems probable at this juncture that the arbitrator would construe the contract to allow class actions, since the alternative would entail vacating his own class arbitration awards. It remains to be seen whether the Court would then revisit the question of whether the FAA somehow prohibits class arbitrations. 
the enforceability of arbitration clauses that strip damages or class action remedies, so a casual reader might say that these cases show a trend toward moving these kinds of enforceability questions into the arbitrator's purview, consistent with a sweeping pro-arbitration policy that will result in more cases, at least the close ones, going to arbitration. Book and Bazzle might also be taken for the less sweeping proposition that contract ambiguity-even on otherwise judicial questions of enforceability of the arbitration agreement-must be resolved by the arbitrator, so that courts may make pre-arbitration rulings only on unambiguous contract terms.

But these broad readings are mistaken. Another key similarity among these cases is that the basic validity threshold was crossed in each. That is to say, there was no question in any of the cases as to "whether the parties have a valid arbitration agreement at all." 143 In Howsam, the parties impliedly conceded that there was a binding arbitration agreement-the question was whether the merits of that dispute could go forward. ${ }^{144}$ In Book, the district court ruled that a valid arbitration agreement existed as to some, if not all, of the non-RICO claims, and that aspect of the ruling was unchallenged on appeal. ${ }^{145}$ In Bazzle, both sides conceded that a valid arbitration existed for the individual claims and disputed only whether a class could be certified for the arbitration. ${ }^{146}$ In contrast, in cases where the overarching validity of the arbitration agreement is in question, it would be premature to defer any issue to an arbitrator, because it has yet to be determined whether a valid arbitration agreement even exists on which to call the arbitration into being. The arbitrator has no legal existence prior to the finding of a valid arbitration agreement.

Nor can it be said that Howsam, Book, and Bazzle dictate that an arbitrator be empowered to decide the validity of his legal existence where an ambiguous contract must be construed to determine that question. This question is not like a court's always having jurisdiction to decide its jurisdiction. Courts exist prior to and independently of the filing of any particular lawsuit, but arbitrators "exist" as disputeresolving entities only if there is a valid contract so empowering them. This is implicit in the Bazzle plurality's statement that "whether the

143. Id. at 2407.

144. See Howsam v. Dean Witter Reynolds, Inc. 537 U.S. 79, 83 (2002).

145. See PacifiCare Health Sys., Inc. v. Book, 123 S. Ct. 1531, 1534 (2003).

146. See Bazzle, 123 S. Ct. at 2405-06 (2003) 
parties have a valid arbitration agreement at all" is a question for courts to decide. ${ }^{147}$

For the future, the question of who decides the enforceability of remedy-stripping provisions can be made clearer if one distinguishes between two different enforceability questions: the "validity" of an arbitration agreement- "whether the parties have a valid arbitration agreement at all"148_ and the particular "arbitrability" question of "whether a concededly binding arbitration agreement applies to a particular type of controversy." 149 I will call this latter question "issue-arbitrability" to distinguish it from other "gateway" disputes that might be referred to as arbitrability questions, such as whether an arbitration agreement binds particular parties.

Even under Book and Bazzle, where a contract ambiguity goes to the validity of the arbitration clause as a whole-where it must be resolved in order to determine whether to conjure the arbitrator into legal existence-it must be for the court. Suppose, as was purportedly the case in Bazzle, an arbitration clause is ambiguous about whether class actions are barred. If the court believes that a class action ban is unconscionable and renders the entire arbitration clause invalid, the court should be allowed to interpret the contract and resolve the ambiguity. If, however, the ambiguity goes only to the arbitration of particular claims, Book and Bazzle may in some cases require that the ambiguity be resolved by the arbitrator.

As explained above, a remedy-stripping provision may be interpreted as making the entire arbitration clause unconscionable and therefore unenforceable in toto. ${ }^{150}$ Alternatively, a court may instead determine that only those claims associated with the excluded remedies will be excluded from the arbitration, but that the remedy-stripping clause will be otherwise enforced-in Paladino, for example, contract claims were to go forward in arbitration; ${ }^{151}$ in Book, the district court originally determined that all but the RICO claims would be compelled into arbitration. ${ }^{152}$ As I see it, the distinction between validity and issue-arbitrability turns, functionally, on whether the court deems the agreement unenforceable in whole, or only in part. If the

147. Id.

148. Id.

149. Id.; accord Howsam, 537 U.S. at 84.

150. See, e.g., Stirlen v. Supercuts, Inc., 60 Cal. Rptr. 2d 138 (Ct. App. 1997); Armendariz v. Found. Health Psychcare Servs., Inc., 6 P.3d 669 (Cal. 2000); Graham Oil Co. v. ARCO Prods. Co., 43 F.3d 1244 (9th Cir. 1994).

151. See Paladino v. Avnet Computer Techs., 134 F.3d 1054, 1060 (11th Cir. 1998).

152. See PacifiCare Health Sys., Inc. v. Book, 123 S. Ct. 1531, 1534 (2003). 
entire agreement is invalid, that is a "validity" determination. If the agreement is unenforceable only as to certain claims, that is an "issuearbitrability" ruling.

While Howsam, Book, and Bazzle defer certain issue-arbitrability questions to the arbitrator, most of these are still for the courts to decide. To begin with, only ambiguous questions of contract interpretation go to the arbitrator, according to the Court. ${ }^{153}$ In Book, for example, the Court deemed the contract ambiguous as to whether it precluded treble damages under the RICO Act. ${ }^{154}$ But it remains for the court to determine the legal effect of such an ambiguity, once resolved, on the issue-arbitrability question. If the Book contract were construed to prohibit an award of treble damages, the Court, not the arbitrator, should determine whether the arbitration clause could be enforced as to the RICO claim. Indeed, the Supreme Court trilogy should be understood to permit a court to make such a determination as a threshold matter. The lower courts on remand in Book can and should be free to rule that if the contract prohibits treble damages, then RICO claims cannot be arbitrated. This only makes sense, since the court in many challenges to remedy-stripping clauses will be asked to decide the threshold question of validity before deciding arbitrability questions.

Furthermore, it should be plain that remedy-stripping clauses like those in Stirlen and Paladino are not ambiguous. While prohibiting the arbitrator from awarding "extra-contractual damages" may or may not exclude RICO treble damages from arbitration, such a provision plainly excludes emotional distress and punitive damages. To be sure, a court could take any of the three approaches, discussed above, to denying enforcement to such a clause. ${ }^{155}$ But it is important to distinguish between the courts' responsive options and an ambiguity in the contract language itself. Judge Hatchett was overly sly in Paladino, when he called the plain remedy-stripping clause "ambiguous" in order to gain interpretive freedom: ${ }^{156}$ after Howsam, Book, and Bazzle, calling the agreement ambiguous improperly takes the arbitrability decision out of the judge's hands and puts it into the hands of the arbitrator. As the separate Cox-Tjoflat opinion correctly observed, the Paladino contract unambiguously with held tort and statutory damages

153. See id. at 1535-36.

154. Id. at 1535.

155. See supra Part II.

156. See Paladino, 134 F.3d at 1057-58. 
remedies from the arbitrator, making the tort and statutory claims non-arbitrable under the agreement. ${ }^{157}$

The validity-arbitrability distinction adds a measure of clarity to a set of decisions that are becoming more doctrinally complicated by the day. These distinctions are also helpful to sort out various arbitration enforcement decisions that could otherwise look like a confused mishmash of federal statutory and state law unconscionability doctrine. Cole v. Burns Intermational Security Services, ${ }^{158}$ for example, held that arbitration of Title VII claims will be enforced if the agreement can be construed as providing procedural safeguards for the plaintiff. ${ }^{159}$ Are cases like Cole "arbitrability" decisions based on an interpretation of Title VII or "unconscionability" decisions finding arbitration-in the context of a Title VII claim-to be too unfair for enforcement as a matter of state law? ${ }^{160}$ Under the distinction I propose, the Cole line of cases are clearly issue-arbitrability decisions, since they presumably do not hold the arbitration agreements invalid in toto. ${ }^{161}$

The distinction also throws into sharp relief some inherent ambiguities about the scope of the Supreme Court's recent decision on excessive arbitration forum fees in Green Tree Financial Corp. v. Randolph. ${ }^{162}$ There, the Court compelled the plaintiff, a mobile-home purchaser, to arbitrate her claim under the federal Truth in Lending Act ("TILA"), ${ }^{163}$ rejecting the plaintiff's contention that arbitration fees would deter her from vindicating her statutory rights. ${ }^{164}$ The Court found plaintiff's contention too "speculative" given the lack of any evidence in the record showing what the fees would be and who would in fact be required to pay them. The future application of Randolph's ap-

157. See id. at 1061-62.

158. 105 F.3d 1465 (D.C. Cir. 1997).

159. See id. at 1485 .

160. Compare id. (analyzing issue as "arbitrability" question requiring interpretation of federal antidiscrimination statute) with Armendariz v. Found. Health Psychcare Servs., Inc., 6 P.3d 669 (Cal. 2000) (applying state unconscionability doctrine).

161. Likewise, the litigation over whether Congress intended to preserve a Title VII plaintiff's right to a judicial forum, notwithstanding a pre-dispute arbitration agreement, is plainly an issue-arbitrability decisions. Compare Duffield v. Robertson Stephens \& Co., 144 F.3d 1182 (9th Cir. 1998) (Title VII claims not arbitrable), overruled by EEOC v. Luce, Forward, Hamilton \& Scripps, 345 F.3d 742 (9th Cir. 2002) (en banc), with Cole, 105 F.3d 1465 (Title VII claims are arbitrable if fair arbitration procedures guaranteed); see Schwartz, supra note 8, at 89-110 (outlining the history of litigation over the now-defunct "public policy exception" to the FAA, and criticizing the Court's abandonment of the exception).

162. 531 U.S. $79(2000)$.

163. 15 U.S.C. $\$ \S 1601-1677 f(2000)$.

164. See Randolph, 531 U.S. at 89. 
parent holding, that a plaintiff must create a factual record to support a "prohibitive costs" argument, can be viewed in three different ways. First, it could be limited to a decision about the arbitrability of TILA claims in particular, in which case it would be distinguishable in cases challenging arbitration clauses in the context of other statutes, such as Title VII. Second, it could be viewed as a broad arbitrability decision applicable to all, or most, federal statutory claims-but not necessarily reaching determinations of unconscionability based on state law. Finally, it could be misconstrued as federal common law of unconscionability - that a finding of unconscionability will not be made on the basis of a cost claim without the specific proof-arguably preempting state law on the subject. But because Randolph deals only with arbitrability of a TILA claim, the case is best understood as an issue-arbitrability, rather than a validity, ruling.

\section{The "Enforce as Written" Rule}

The "enforce as written" argument urged by the defendants in Bazzle potentially goes beyond the class action issue featured in that case to include other remedy-stripping provisions. ${ }^{165}$ Parties defending such arbitration agreements have argued that the FAA requires that such agreements be enforced "according to their terms" or "as written" as a matter of preemptive federal law, and that any state law doctrine that would deny full enforcement to all the terms grafted onto the arbitration agreement is preempted. ${ }^{166}$

With such a rule, FAA preemption threatens to become a gaping maw that would swallow all state contract law-that, at least, seems to be the hope of the proponents of the argument. A rule requiring enforcement of an agreement literally "according to its terms" does indeed conflict with a rule holding that, for instance, unconscionable terms will not be enforced, and such a federal enforcement rule would trump the state unconscionability rule. Because only a federal common law of contract defenses would withstand this preemption

165. It could also be applied to provisions requiring arbitration in distant venues, onesided arbitration procedures, and prohibitive costs. See, e.g., Bradley v. Harris Research, 275 F.3d 884 (9th Cir. 2001) (enforcing venue provision in arbitration agreement); Discover Bank v. Super. Ct., 129 Cal. Rptr. 2d 393, 408 (Ct. App. 2003) (suggesting that FAA preempts any departure from enforcing arbitration agreements as written).

166. See, e.g., W. Va. ex rel. Dunlap v. Berger, 567 S.E.2d 265, 279-80 (W. Va. 2002), cert. denied, 537 U.S. 1087 (2002) (drafting party argued that FAA preempts application of state unconscionability doctrine to arbitration agreement purporting to waive punitive damages); Discover Bank, 129 Cal. Rptr. 2d at 408 (suggesting that FAA preempts any departure from enforcing arbitration agreements as written). 
doctrine, the "enforce as written" rule would effectively immunize arbitration agreements from any review whatsoever for fairness under state law.

The "enforce as written" rule misconstrues the FAA. The FAA permits drafting parties to control only one particular aspect of dispute resolution - the choice of arbitration or court. The Act expresses no "federal policy" against state laws that protect consumers (or employees or other adhering parties) from having unfavorable dispute rules imposed on them distinct from the simple choice of arbitration over litigation. There is no "national policy" favoring oppressive venue clauses, waiver of class action remedies, waiver of damages remedies, one-sided arbitration procedures, or other unconscionable terms, even if such terms can be grafted onto an arbitration agreement. The Supreme Court has never adopted a blanket federal rule of contract law that arbitration agreements are to be enforced "according to their terms" irrespective of general state contract law. On the contrary, the Supreme Court has been careful to point out that "commercial arbitration agreements, like other contracts, are enforced according to their terms and according to the intentions of the parties." 167 This means that, like other contracts, arbitration agreements are subject to a state's "generally applicable contract defenses" and rules that "arose to govern . . . contracts generally[.]"168

The law of contract guarantees no one an absolute right to have a private written agreement enforced exactly "as written." All contracts are subject to background state contract law, which will provide, as a matter of public policy, that certain terms cannot be enforced as written. The recognized purpose of the FAA is to place arbitration agreements "upon the same footing as other contracts," 169 and to "make arbitration agreements as enforceable as other contracts but not more so." 170 This precludes the idea that the FAA can serve as special national exemption from state contract law that applies to arbitration agreements but no other contracts.

Nevertheless, the Bazzle Court did not take the opportunity to kill off this misguided view of the FAA. Although Justices Stevens and Thomas would clearly oppose imposition of the "enforce as written"

167. First Options of Chi., Inc. v. Kaplan, 514 U.S. 938, 947 (1995) (internal quotations omitted); Volt Info. Scis., Inc. v. Bd. of Trs., 489 U.S. 468, 478 (1989) (the FAA "simply requires courts to enforce privately negotiated agreements to arbitrate, like other contracts, in accordance with their terms") (emphasis added).

168. Doctors Assocs., Inc. v. Casarotto, 517 U.S. 681, 686-87 (1996).

169. H.R. ReP. No. 96, 68th Cong., 1st Sess. 1 (1924); accord Volt, 489 U.S. at 479.

170. Prima Paint Corp. v. Flood \& Conklin Mfg. Co., 388 U.S. 395, 404 n.12 (1967). 
rule, ${ }^{171}$ the four justice plurality did not address this issue one way or the other. And Chief Justice Rehnquist, in a dissent joined by Justices Kennedy and O'Connor, argued that the contract "simply" precluded class arbitrations and therefore had to be enforced "according to [its] terms" under the FAA; the application of a state law rule to vary those written terms should have been preempted by the FAA. ${ }^{172}$ The Rehnquist dissent thus appears to have endorsed the "enforce as written" rule, at least for class actions, giving contract drafters the power to override state statutory and judge-made law that would prohibit forced waivers of class actions.

Wrong as it is, the "enforce as written" rule survives for now, raising the question: how would courts enforcing remedy-stripping arbitration clauses reconcile such arbitrations with Gilmer's assurance that arbitration waives no substantive rights? Enforcement of the remedy limitation tells us nothing about the res judicata effects of the arbitration that would be had under such an agreement. As will be seen below, proper application of preclusion principles could take much of the bite out of a rule that remedy-stripping arbitration clauses must be "enforced as written." In short, arbitrations under such agreements should not preclude subsequent litigation of excluded claims and remedies.

\section{Applying Preclusion Principles to Partially Enforced Remedy-Stripping Clauses}

If a remedy-stripping arbitration clause is held unenforceable in its entirety, there is of course no arbitration and, therefore, no question about the preclusive effect of a prior arbitration. While the validity approach to remedy-stripping agreements remains viable, the persistence of an arbitrability approach means that some remedy-stripping arbitration agreements will be partially enforced: some issues will be sent to arbitration and others will not. This raises preclusion questions. In federal courts, at least, cases involving such "intertwined" arbitrable and non-arbitrable claims are governed by the doctrine of

171. Justice Stevens wrote a separate opinion, stating that the question of whether an arbitration agreement should be construed to allow class actions was one of state law-in essence, that state law governs the construction of an arbitration agreement. Green Tree Fin. Corp. v. Bazzle, 123 S. Ct. 2402, 2408 (2003) (Stevens, J., concurring in the judgment and dissenting in part). Justice Thomas, adhering to his position that Southland Corp. $v$. Keating, 465 U.S. 1 (1984) was wrongly decided, issued a separate dissent arguing that the South Carolina judgment should have been affirmed because the FAA does not apply in state court. Bazzle, 123 S. Ct. at 2411 (Thomas, J., dissenting).

172. Bazzle, 123 S. Ct. at 2410-11 (Rehnquist, C.J., dissenting). 
Dean Witter Reynolds Inc. v. Byrd, ${ }^{173}$ which requires the court to stay litigation pending completion of the arbitration. Moreover, the emergence of the "enforce as written" argument raises the specter of another form of partial enforcement, in which the arbitrator might decide all liability issues but be allowed to award only limited-for instance, only contract-damages. Both these scenarios raise the question: what preclusive effect should be accorded such an arbitration?

After reviewing the Byrd "intertwining doctrine," this section considers three possible applications of preclusion principles to the subsequent litigation of non-arbitrable claims. First, a court could bifurcate liability and remedy, ordering the arbitrator to decide liability and leaving only the remedy question for subsequent litigation. Second, under a "collateral estoppel" approach, the court could reserve for itself any claims for which the arbitrator is not authorized to award full relief, but give collateral estoppel effect to factual issues decided by the arbitrator. Third, under a "res judicata" approach, the court could forego the case-by-case issue preclusion determinations necessitated by the second approach, by fully relitigating all issues necessary to decide the claims not decided by the arbitrator. I argue that the res judicata approach, which gives the narrowest preclusive effect to the arbitration, best serves the policy of deterring the drafting of remedystripping clauses. Finally, I discuss how applying preclusion principles to arbitration clauses banning class actions should work to prevent drafters from immunizing themselves from classwide liability.

\section{A. The Intertwining Doctrine: Arbitrable and Non-Arbitrable Claims}

In theory, one could imagine an interpretation of the FAA as allowing a court to protect its own jurisdiction and promote efficiency of dispute resolution by refusing to compel arbitration-or at least putting off arbitration-where a small piece of a lawsuit is arbitrable while a bigger piece is to be decided in the judicial forum. But such an approach has long been foreclosed by federal doctrine that requires arbitration to proceed first, even if the result is "piecemeal" dispute resolution. ${ }^{174}$ Whether this rule binds state courts remains unclear.

173. 470 U.S. 213 (1985).

174. See Moses H. Cone Mem'l Hosp. v. Mercury Constr. Corp., 460 U.S. 1, 20 (1983). 


\section{Federal Law: Piecemeal Litigation, Arbitration First}

In Moses H. Cone Memorial Hospital v. Mercury Construction Corp., ${ }^{175}$ the Supreme Court determined that federal courts would have no discretion to stay arbitration in favor of pending state-court litigation. ${ }^{176}$ The hospital brought an action in state court against two parties, one a construction company with which it had a contract containing a broad arbitration clause, and the other, an architect with whom the hospital had no arbitration agreement. ${ }^{177}$ Although the litigation could have resolved all claims among the parties, whereas the arbitration would have left the hospital's claim against the architect unresolved, the Court held that the state court action had to be stayed pending arbitration. ${ }^{178}$ The FAA, according to the Court, "requires piecemeal resolution when necessary to give effect to an arbitration agreement." 179 Efficiency concerns thus could not allow a court to make an arbitration moot by resolving all claims in court.

Nor can courts put off the arbitration until after litigation to promote efficient dispute resolution. In Byrd, the plaintiff, an investor, sued his broker under state common law theories, which were arbitrable, and federal securities law claims, which were deemed non-arbitrable at that time. ${ }^{180}$ Various lower courts had held that arbitration should not be compelled where arbitrable claims were "intertwined" with non-arbitrable federal statutory claims. By requiring the litigation of the federal claims to precede arbitration, the courts would both avoid inefficient duplication of fact finding and prevent the possibility that a prior fact finding in arbitration would by collateral estoppel effectively prevent the court from hearing the federal claim. ${ }^{181}$ But the Supreme Court dismissed both these concerns, holding that courts must enforce an arbitration clause by staying litigation of the non-arbitrable claim, and compelling the arbitrable claims into arbitration, "even where the result would be the possibly inefficient maintenance of separate proceedings in different forums" for the same pair of adversaries. ${ }^{182}$ First, the Court declared that the overriding

175. 460 U.S. 1 (1983).

176. See id. at 19-20.

177. See id.

178. See id.

179. Id. at 20.

180. See Wilko v. Swan, 346 U.S. 427 (1953) (holding that claims arising under section 12(2) of the Securities Act of 1933 could not be compelled into arbitration), overruled by Rodriguez de Quijas v. Shearson/American Express Inc., 490 U.S. 477 (1989).

181. See Dean Witter Reynolds Inc. v. Byrd, 470 U.S. 213, 215 (1985).

182. Id. at 217. 
goal of the FAA was not to promote the expeditious resolution of claims, but simply to enforce agreements to arbitrate. ${ }^{183}$ Second, a party's right to have non-arbitrable claims litigated would be protected adequately by framing appropriate preclusion rules, not by allowing litigation to proceed first. ${ }^{184}$ Significantly, the Court found it "far from certain that arbitration proceedings will have any preclusive effect on the litigation of nonarbitrable federal claims." 185

\section{The Applicability of the Federal Rule in State Court}

FAA section 2 provides that arbitration agreements are "valid, irrevocable and enforceable, save upon such grounds as exist at law or in equity for the revocation of any contract." 186 The applicability of this purportedly "substantive" law rule in state court is at present, though controversial, well established. ${ }^{187}$ Whether the procedural enforcement provisions of FAA sections 3 and 4 apply in state court has not been decided, and in declining to reach the issue, the Supreme Court has noted that the argument against the applicability of these sections in state court proceedings "is not without some merit." 188

In Volt Information Sciences $v$. Board of Trustees of Leland Stanford Junior University, ${ }^{189}$ the Court was asked to consider the closely related question of whether the Byrd rule, requiring arbitration to precede litigation on intertwined issues between the same parties, applied to a proceeding in California state court. California's controlling civil procedure statute provides that a court has discretion to stay either the

183. See id.

184. See id. at 222-24.

185. Id. at 222 .

186. FAA $\S 2,9$ U.S.C. $\S 2$ (2000).

187. See, e.g., Circuit City Stores v. Adams, 532 U.S. 105, 121 (2001) (declining to reconsider FAA preemption of state law); Allied-Bruce Terminix Cos. v. Dobson, 513 U.S. 265, 272 (1995) (declining to reconsider FAA preemption of state law). For criticism of the doctrine of FAA preemption, see Schwartz, supra note 19; David S. Schwartz, States Judges as Guardians of Federalism: Resisting the Federal Arbitration Act's Encroachment on State Law 2-15 (July 19, 2003) (paper presented to Roscoe Pound Institute's 2003 Forum for State Court Judges), available at http://www.roscoepound.org/new/updates/schwartz/pdf (last accessed October 31, 2003); Brief for Law Professors as Amici Curriae in Support of Respondents, Green Tree Fin. Corp. v. Bazzle, 123 S. Ct. 2402 (2003) (No. 02-634); but see Christopher R. Drahozal, In Defense of Southland: Reexamining the Legislative History of the Federal Arbitration Act, 78 Notre Dame. L. Rev. 101 (2002).

188. Volt Info. Scis. v. Bd. of Trs., 489 U.S. 468, 477 \& n.6 (1989) (declining to resolve issue of whether FAA $\$ \S 3,4,9$ U.S.C. $\$ \S 3,4$ apply in state court); see also Southland Corp. v. Keating, 465 U.S. 1, 29 (1984) (O'Connor, J., dissenting) (arguing that FAA $\$ \$ 3,4$ do not apply in state court); Allied Bruce Terminix Cos. v. Dobson, 513 U.S. 265, 285 (1995) (Thomas, J., dissenting).

189. 489 U.S. 477 (1989). 
arbitration or the litigation in such circumstances, based on efficiency and fairness concerns. ${ }^{190}$ The Supreme Court held that the federal rule did not preempt the state rule where, as in that case, the parties' arbitration agreement contained a choice of law clause construed as adopting California procedural law. ${ }^{191}$ The Court concluded that the "substantive" policy of FAA section 2 did not require arbitration to precede litigation in state court where that reversal of the Byrd rule appeared consistent with the parties' contractual choice. ${ }^{192}$

Volt dodged the bigger question of whether the FAA should be interpreted as dictating procedures to state courts. Such an interpretation-whether it would impose the procedures spelled out in FAA sections 3 and 4, or the procedural mandate of Byrd that arbitration must go first in intertwined cases-raises grave constitutional doubts. States' power over their own judicial procedures has been recognized as part of the core of their sovereignty, and the power of Congress to dictate procedural rules to state courts is extremely limited, if it exists at all. ${ }^{193}$

In any event, the significance of the question for present purposes is that the Byrd rule raises the special problem of the preclusion effects of a prior arbitration on intertwined claims litigated afterwards. If state procedural law allows the litigation to proceed first, this problem is obviated. But assuming the Byrd rule is applied, one could imagine courts taking any of the following three plausible approaches to the preclusion issue.

\section{B. Bifurcating Liability and Remedy}

An arbitration clause that purports to apply to all claims that might arise out of or relate to the parties' contractual relationship,

190. See Cal. Civ. Proc. Code $\$ 1281.2$ (c) (1998).

191. See Volt, 489 U.S. at $477-79$.

192. In fact, the Volt Court did not even construe the contract, but instead relied on the state court's interpretation that a California choice of law clause incorporated the California rule allowing a court to order intertwined litigation to precede arbitration. The United States Supreme Court found the contract interpretation to be a matter of state law, which had been authoritatively construed by the state court. Id. at 479 ; see supra text accompanying note 168 .

193. In the absence of a state rule that uniquely burdens a federal "right of recovery" by imposing particular procedural obstacles, it is doubtful whether any federal power to control neutral state procedures in federal question cases exists at all. See Johnson v. Fankell, 520 U.S. 911, 919 (1997) (holding that neutral state rule denying interlocutory appeals is not preempted by federal rule allowing such appeals for section 1983 defendants); Howlett v. Rose, 496 U.S. 356, 372 (1990) (normally, "ffederal law takes the state courts as it finds them'" (quoting Hart, The Relations Between State and Federal Law, 54 Colum L. Rev. 489, 508 (1954)); Schwartz, supra note 187, at 10-14. 
but that restricts remedies, could-at least as a logical matter-be construed as calling for a bifurcated proceeding in which questions of remedy are adjudicated separately from questions of liability.

Take the Stirlen case as an example, in which the plaintiff has contract, tort, and statutory claims. The litigation might proceed in the following way: The plaintiff files the lawsuit, the defendant moves to compel arbitration. The court construes the remedy limitation as withholding only those remedy questions from the arbitrator, but enforces the general arbitrability language-stating that all claims arising out of employment are to be arbitrated-as applying to the liability issues on those claims. The court thus compels arbitration but retains jurisdiction over any issues of remedy unresolved by the arbitration. The arbitration goes forward on all liability issues and the arbitrator awards contract remedies, if appropriate. Assuming that liability were found on a claim for which extra-contractual damages could be awarded-a tort or statutory claim-the plaintiff would then return to court for the adjudication of those issues.

In short, the remedy-stripping clause would be construed in the same manner as an arbitration agreement affirmatively seeking to bifurcate liability from damages, which might look like this:

The parties agree that any dispute arising out of or relating to Employee's employment with Company shall be submitted to final and binding arbitration. The arbitrator shall resolve all issues of liability, but shall be authorized to award only damages for breach of contract, if any. Damages for any other claim on which liability has been found by the arbitrator shall be determined in a court of law, subsequent to the arbitration.

On the surface, this "bifurcation" approach has the virtue-if it can be called a virtue-of enforcing both the broad arbitrability provision in a Stirlen-type remedy-stripping clause and the remedy limitation, but without depriving the plaintiff of remedies. Those who believe-inaccurately, in my view-that the Supreme Court's "liberal federal policy favoring arbitration agreements" 194 means more arbitration is always to be preferred to less can take satisfaction in a result in which more issues are arbitrated than otherwise. The (remedy-stripping) arbitration clause gets the widest scope consistent with the Supreme Court's caution that arbitration should not result in the loss of substantive rights.

194. Gilmer v. Interstate/Johnson Lane Corp., 500 U.S. 20, 25 (1991) (quoting Moses H. Cone Mem'l Hosp. v. Mercury Constr. Corp., 460 U.S. 1, 24 (1983)). 
Yet, on balance, "bifurcation" has little to recommend it as an approach to remedy-stripping clauses. To begin with, "the FAA's proarbitration policy does not operate without regard to the wishes of the contracting parties." 195 As discussed above with respect to the Paladino "arbitrability" approach, this reinterpretation of the remedystripping clause really gives neither side what it wants. The non-drafting plaintiff wants litigation, not arbitration. The drafter wants a forced remedy waiver, not a bifurcated proceeding. Had a bifurcated proceeding been what was intended, the above language is readily available to express that intent; the failure of the drafting party to draft, in clear and express terms, a bifurcated proceeding shows the lack of an intent to have such a proceeding. Indeed, it seems very unlikely that many corporate drafters would go in for the bifurcated approach: a salient appeal of arbitration agreements is the perceived benefit of having the arbitrator decide all damage questions, thereby preventing juries from deciding damages. While it might be said that the allure of arbitration includes limiting discovery on the liability issues, many of these discovery processes could resurface in much the same form to resolve damages issues, particularly punitive damages, which are based on the character of the defendant's conduct.

A bifurcated approach is probably a distant third choice for the drafter, behind (1) construing the clause to force a waiver of remedies, and (2) fully arbitrating all issues. Defendants who have defended remedy-stripping clauses in court have often suggested the second alternative as a fallback position, but have never suggested bifurcation. That, together with the apparent absence in practice of "bifurcated" arbitration agreements, underscores that the defendant wants to strip remedies, not to bifurcate proceedings. As the Supreme Court has made clear, "we do not override the clear intent of the parties, or reach a result inconsistent with the plain text of the contract, simply because the policy favoring arbitration is implicated." 196

Further, it is questionable whether bifurcated proceedings should be permitted even if properly drafted. While it has been said that arbitration agreements must be enforced even if the result is the ineffi-

195. Mastrobuono v. Shearson Lehman Hutton, Inc., 514 U.S. 52, 57 (1995), quoted in EEOC v. Waffle House, 534 U.S. 279, 289 (2002).

196. Waffle House, 534 U.S. at 294. The argument against bifurcation is perfectly consistent with Professor Ware's argument that it is the pre-dispute, contractual intent that is determinative in construing the contract. See supra note 88 . Given the ease with which a clear bifurcation agreement could be drafted, there can be no serious contention that the drafter intended a bifurcated proceeding when it failed to specify one clearly in the agreement. 
cient maintenance of separate arbitral and judicial proceedings, ${ }^{197}$ permitting arbitration clauses to bifurcate liability and remedy is an open invitation to maximize inefficiency. Many damages issues are so intertwined with liability that liability evidence would have to be presented in full in a subsequent damages trial. For example, a plaintiff claiming emotional distress from sexual harassment would have to present evidence about the severity of the harassing conduct in order to prove her emotional distress damages, thereby duplicating what the arbitrator would have heard to decide the "severe or pervasive" element of the harassment claim. ${ }^{198}$ Likewise, punitive damages require evidence of the defendant's malicious conduct, which necessarily includes the conduct giving rise to tort liability. ${ }^{199}$

Finally, the bifurcation approach lets the defendant off too easy. Having drafted a remedy-stripping clause in the hope of gaining an unlawful advantage, rather than a true bifurcation clause, the bifurcation approach rewards this defendant by allowing arbitration of more issues than under the collateral estoppel or res judicata approaches described below. Yet, for reasons discussed above, drafters of arbitration clauses should be discouraged from drafting remedy-stripping provisions. Bifurcation does not go far enough, compared with the approaches below.

\section{A Collateral Estoppel Approach}

Under a "collateral estoppel" approach, claims carrying remedies excluded from the arbitration would likewise be excluded from the arbitration. ${ }^{200}$ In the employment hypothetical, in which all remedies are excluded except contract damages, the arbitration would decide only the contract claims. Tort and statutory claims would be reserved

197. See supra text accompanying notes $175-82$.

198. Sexual harassment must be "severe or pervasive" to give rise to liability under Title VII. See, e.g., Nat'l R.R. Passenger Corp. v. Morgan, 536 U.S. 101, 116 (2002). To prove a defendant's liability for emotional distress damages, a plaintiff must show that the harassment caused the emotional distress. See, e.g., Bailey v. Runyon, 220 F.3d 879, 881 (8th Cir. 2000 ). Evidence of severity or pervasiveness of the harassment is relevant not only to the causation issue, see id., but also to the amount of damages that should be awarded. See Baker v. John Morrell \& Co., 249 F. Supp. 2d 1138, 1193 (N.D. Iowa 2003) (holding that evidence of "severe and pervasive, unremedied harassment" supported award of $\$ 300,000$ in emotional distress damages).

199. See Kolstad v. Am. Dental Ass'n, 527 U.S. 526, 535-37 (1999).

200. Although the Paladino court did not discuss the collateral estoppel implications of the arbitration it was ordering on the subsequent litigation of the non-contractual claims, this collateral estoppel approach would apply to cases that followed Paladino's arbitrability analysis. Paladino v. Avnet Computer Techs., 134 F.3d 1054 (11 th Cir. 1998). 
for the court, and under the Byrd rule, would be adjudicated after the arbitration. However, the factual findings of the arbitration would be accorded collateral estoppel effect in the same way they would be had the arbitration agreement been written explicitly to include contract claims but to exclude all other claims. ${ }^{201}$

These collateral estoppel implications are far from settled, and in any event should probably give rise to case-by-case determinations. The four factors-identity of issue, identity of parties, actually litigated and necessary to the award, and full and fair opportunity to litigate-must all be established for the arbitration to collaterally estop any liability determinations in the subsequent litigation. In most cases, the doubts, if any, would surround the identity of issue and full and fair opportunity factors.

Suppose a plaintiff, under our "contract damages only" arbitration clause, claims that she was wrongfully terminated from employment (1) in breach of an implied contract to terminate only for good cause and (2) in violation of Title VII's prohibition of sex discrimination. Under the collateral estoppel approach, her contract claim is compelled into arbitration. Suppose further that the employer defends the contract claim on alternative theories: (a) there is no implied contract, but rather at-will employment allowing it to discharge the employee without good cause; and (b) in any event, there was good cause to fire her: poor job performance. Several collateral estoppel outcomes are possible.

If the employer wins on the ground that there is no implied contract, that issue should not collaterally estop the plaintiff from going forward with the full-blown Title VII claim in court. Title VII supercedes the at-will rule-that is to say, an employer can fire an employee without cause under at-will employment without breaching any contract, but if the reason turns out to be sex discrimination, Title VII is nevertheless violated. The at-will employment status, although dispositive of the contract claim, is irrelevant to the subsequent Title VII claim. ${ }^{202}$

But if the employer wins on the ground that the employee was fired for good cause-poor performance-there is an argument that collateral estoppel bars relitigation of the reasons for discharge, or at

201. See Lagatree v. Luce, Forward, Hamilton \& Scripps, 88 Cal. Rptr. 2d 664, 668 (Ct. App. 1999) (arbitration clause excluding statutory claims).

202. See, e.g., Pivirotto v. Innovative Sys. Inc., 191 F.3d 344, 350-51 (3d Cir. 1999); see also Skinner v. Maritz, Inc., 253 F.3d 337 (8th Cir. 2001) (holding that at-will employment status cannot defeat race discrimination claim under 42 U.S.C. $\$ 1981$ (2001)). 
least conclusively establishes the fact that plaintiff performed poorly enough to justify firing her. This may not insulate the employer from liability, if plaintiff could show that discrimination also figured into the employer's motive. ${ }^{203}$

The defendant's potential to succeed in asserting collateral estoppel is complicated by two additional factors relating to the nature of arbitrations. First, arbitrations do not always create a sufficient record to enable a reviewing court to determine whether the identical issue was decided. ${ }^{204}$ Arbitrations are typically conducted without the creation of a reporter's transcript, and traditionally, arbitrators do not issue awards containing written reasons-although there is something of a trend among some arbitration providers to require written reasons in certain kinds of cases. ${ }^{205}$ If the arbitrator in this example issued an award simply concluding that there was "no breach of contract," there would be an ambiguity as to whether the arbitrator found good cause to fire the employee. A reviewing court could not collaterally estop the plaintiff from fully relitigating the issue.

Second, the informality of arbitrations will tend to raise questions about whether a losing plaintiff had a "full and fair opportunity to litigate" the issue that the defendant asserts is barred. This is particularly true where the defendant may possess critical information-as is typical of employment cases, for instance-but where little or no discovery has been allowed. A blanket rule that views arbitration as less than a full and fair opportunity to litigate would undermine the concept of according preclusive effect to arbitration awards, so it is not surprising that the "full and fair opportunity" prong of collateral estoppel has been held to mean the satisfaction of minimal due process safeguards in the arbitration collateral estoppel context. ${ }^{206}$ Nevertheless, where statutory public policy claims are concerned, such as employment discrimination, case law requiring higher minimum thresholds for procedural adequacy would support a more rigorous examination of the plaintiff's opportunities to conduct discovery and present evidence in the arbitration. ${ }^{207}$ Where discovery was unduly

203. See Desert Palace, Inc. v. Costa, 123 S. Ct. 2148, 2151 \& n.2 (2003); 42 U.S.C. $\S 2000 \mathrm{e}-5(\mathrm{~g})(2)(\mathrm{B})(2001)$.

204. See Postlewaite v. McGraw-Hill, Inc., 333 F.3d 42 (2d Cir. 2003) (denying collateral estoppel where basis for arbitrator's award was unclear).

205. See Schwartz, supra note 8, at 48-50 nn.40-46. But see Am. Arbitration Ass' N, NATiOnal, Rules for the Resolution of Employment Disputes (2002).

206. See, e.g., Witkowski, M.D. v. Welch, 173 F.3d 192, 205 (3d Cir. 1999).

207. See, e.g., Cole v. Burns Int'l Sec. Servs., 105 F.3d 1465 (D.C. Cir. 1997) (valid arbitration of Title VII claims must provide certain amount of discovery and other procedural 
limited, the plaintiff could rely on such cases to make a strong argument that she did not have a full and fair opportunity to present her claim, resulting in denial of collateral estoppel.

Very pertinent here is the suggestion in Byrd that it is incumbent on federal courts to create preclusion rules that protect federal statutory rights where intertwined common law claims are adjudicated first. ${ }^{208}$ To be sure, Byrd was decided before the four Supreme Court arbitrability rulings that held that most federal statutory claims are amenable to compelled arbitration under pre-dispute agreements. ${ }^{209}$ But these subsequent decisions do not vitiate Byrd's concern about claim preclusion. Although a federal statutory claim could now in theory be subject to an arbitration clause, Byrd should still be good law in the present context, where the federal statutory claim is in fact excluded from arbitration due to the court's construction of a remedystripping provision. In this situation, as in Byrd, a private law claim is arbitrated while the federal statutory claim waits its turn to be litigated.

One of these special preclusion rules anticipated in Byrd may be to favor the use of offensive collateral estoppel by plaintiffs. Suppose the plaintiff wins her contract claim, necessarily implying a finding that there was not good cause to terminate her-that the employer's proffered explanation of poor performance was a pretext covering up a lack of good cause. The employer should, in such instance, be collaterally estopped from asserting poor performance as the reason for discharge in the sex discrimination claim in court; the only issue for liability would be whether the plaintiff's sex motivated the discharge.

Fair enough. But suppose the employer wished to complain about the lack of clarity in the record about the arbitrator's reasoning or in the award, or a lack of opportunity to conduct discovery or otherwise fully or fairly litigate the contract issue? Absent a showing of some sort of abuse or evident partiality on the part of the arbitrator, such an argument should be rejected on grounds of equitable estop-

protections not traditional in arbitration); Armendariz v. Found. Health Psychcare Servs., Inc., 6 P.3d 669 (Cal. 2000).

208. See Dean Witter Reynolds Inc. v. Byrd, 470 U.S. 213, 222-24 (1985).

209. See Mitsubishi Motors Corp. v. Soler Chrysler-Plymouth, Inc., 473 U.S. 614 (1985) (holding that Sherman Antitrust Act claims were subject to compelled arbitration); Shearson/American Express Inc. v. McMahon, 482 U.S. 220 (1987) (holding that Securities Exchange Act and RICO claims were subject to compelled arbitration); Rodriguez de Quijas v. Shearson/American Express Inc., 490 U.S. 477 (1989) (holding that Securities Act claims were subject to compelled arbitration); Gilmer v. Interstate/Johnson Lane Corp., 500 U.S. 20 (1991) (holding that ADEA claims were subject to compelled arbitration). 
pel. If the defendant imposed the arbitration agreement in an adhesion contract-as a condition of employment or of doing businessand later moved to compel arbitration, it should not subsequently be heard to complain about the disadvantages accruing to it from the informality of the very type of proceeding it insisted upon all along. In this sense, the scrutiny given by courts to arguments against collateral estoppel need not-and should not-be symmetrical, where there is asymmetry in the extent to which the parties exercised free choice in having the arbitration in the first place.

In sum, the collateral estoppel approach treats a remedy-stripping clause in the manner suggested by Judge Hatchett in Paladino: as though it were all along a contract expressly limiting issue-arbitrability. This will lead to the application of collateral estoppel to some issues decided in arbitration when a party seeks to raise them in the subsequent judicial proceeding.

\section{A Res Judicata Approach}

Under a res judicata approach, the court would give preclusive effect to the resolution of the arbitrated claims-in our employment hypothetical, to the breach of contract claim--but nothing more. All remaining issues could be fully litigated, even though certain issues or facts found by the arbitrator would be adjudicated from scratch. Clearly, there is no question of merger or bar in this situation, because the theories and claims to be litigated were excluded from the arbitration by the terms-as construed-of the agreement. Plainly, the res judicata approach gives narrower scope to the prior arbitration. This could be applied symmetrically, with neither defensive nor offensive collateral estoppel applied to issues resolved in the arbitration. Or it could be applied asymmetrically, with the non-drafting party permitted to employ offensive collateral estoppel. The rationale for such a rule would be to punish and deter drafters of remedy-stripping clauses for overreaching.

Another benefit of the res judicata approach to remedy-stripping agreements is that it does away with the uncertainty of the fact-intensive, case-by-case issue preclusion inquiry. It is much easier to tell what legal claims were raised in the arbitration-one need look only at the arbitrability ruling of the court compelling arbitration, the plaintiff's arbitration demand, and the award-than to determine the factual and subsidiary issues necessarily resolved in rendering the award, whether they are identical to those in the subsequent case, and whether they were fully and fairly litigated. 
This approach is consistent with the interpretation of GardnerDenver. ${ }^{210}$ To be sure, since Gilmer, the applicability of Gardner-Denver and its progeny seems to have been limited to the context of collective bargaining agreements. But there are reasons to apply Gardner-Denver's res judicata approach to remedy-stripping arbitration clauses, notwithstanding that such clauses occur invariably outside the union setting, and to apply it to statutory claims as well as any other claims excluded from the arbitration. To begin with, where the parties' contract excludes statutory and tort claims, it is the drafting party-and not the court-that has expressed some sort of distrust for the process of arbitration. While the FAA reverses "the old judicial hostility to arbitration," it is supposed to respect the parties' contractual choice to withhold issues from arbitration. ${ }^{211}$ Where an arbitration clause reserves some issues for adjudication, there is some force to the idea that the parties intended the arbitrator to decide only the claims presented in arbitration, while reserving the full authority of the court to resolve those claims withheld from arbitration.

Furthermore, Gardner-Denver rests in part, not on disrespect for arbitration or arbitrators, but on the limitations placed on that forum by contract terms limiting the arbitrator's mandate. A contract limiting the scope of arbitration to private law or, in particular, to contract matters, could render irrelevant to the arbitration proceeding many facts that would be significant to the litigated claims. For example, a remedy-stripping clause whose effect is to exclude statutory claims in effect instructs the arbitrator not to pay particular attention to discrimination issues, which often turn on subtle circumstantial evidence of intent. A fact finder directed to look for such intent evidence might well have a very different impression on some of the same issues. For example, the question of whether plaintiff's performance was sufficiently poor to warrant firing her might look very different in the contract case than in the discrimination case. Rather than making case-bycase determinations of whether the identical issue was fully litigatedas required by the collateral estoppel approach-the res judicata approach decides this question categorically, adding a measure of certainty and simplification to the question of "relitigation."

Finally-and perhaps most importantly-it must be pointed out again that we are not for the most part talking about arbitration clauses that reserve non-arbitrable issues in good faith. Whatever

210. See supra text accompanying notes 63-67.

211. See, e.g., EEOC v. Waffle House, Inc., 534 U.S. 279, 293-94 (2002); Volt Info. Scis., Inc. v. Bd. of Trs., 489 U.S. 468, 479 (1989). 
merit there may be to giving collateral estoppel effect to a prior arbitration in the subsequent litigation of intertwined, non-arbitrable claims is weakened when we are talking about remedy-stripping clauses. Remedy-stripping clauses are a form of contractual overreaching by drafters who hope to impose unlawful, pre-dispute waivers of substantive rights on their customers or employees. This is behavior for which a deterrent is appropriate. For a party that wants to impose arbitration, a res judicata approach, by protecting more issues for litigation, creates more of a deterrent. It is fully appropriate for courts to craft a set of special preclusion rules in order both to deter improper use of arbitration clauses and to protect the substantive interests of the various statutory claims affected by remedy-stripping clauses. ${ }^{212}$

\section{E. The Problem of Class Actions}

At first blush, class actions appear to create a different issue from other remedy-stripping arbitration clauses. Class actions seem to be a matter of procedure, whereas the right to reccver damages or obtain equitable relief seems far more "substantive." But on closer examination, the issues are more the same than different, and a growing number of decisions are finding class action bans unconscionable. ${ }^{213}$ An arbitration clause purporting to ban class actions should be unen-

212. See Byrd, 470 U.S. at 223 (court may preserve substantive rights by framing appropriate preclusion rules). In the analogous case of the collateral estoppel effect of unreviewed administrative agency decisions, the Court has observed that "[a]lthough administrative estoppel is favored as a matter of general policy, its suitability may vary according to the specific context of the rights at stake, the power of the agency, and the relative adequacy of agency procedures." Astoria Fed. Sav. \& Loan Ass'n v. Solimino, 501 U.S. 104, 109-10 (1990).

Professor Shell has argued, and some courts have suggested, that the contracting parties' intent regarding the preclusive effect of their arbitration should control. See Shell, supra note 6, at 657-73. However, Professor Shell advances the argument in the context of arbitration agreements between commercial parties, and doesn't expressly consider how gross disparities in bargaining power or the problem of adhesion contracts would affect his analysis. Moreover, he soundly acknowledges that courts, rather than contracting parties, should retain control over preclusion principles to protect important statutory policies and regulatory interests. Id. at 671-73. To allow preclusion principles to be dictated by drafters of adhesion contracts would simply breathe new life into the drafters' power to strip remedies by contract and otherwise tilt the dispute resolution process in the drafters' favor. Courts would then have to scrutinize contractual "res judicata/collateral estoppel" clauses for fairness under unconscionability doctrine. But why impose that extra analytical step? It would be much simpler to maintain the courts' full authority over preclusion principles rather than to allow contracting parties to determine them.

213. See, e.g., Ingle v. Circuit City Stores, 328 F.3d 1165, 1175-76 (9th Cir. 2003) (holding that arbitration clause banning consumer class actions unconscionable and therefore void); Ting v. AT\&T, 319 F.3d 1126, 1150 (9th Cir. 2003) (holding that arbitration clause banning consumer class actions unconscionable and therefore void). But see Green Tree 
forceable, and a res judicata approach could resolve this question as well.

To begin with, it seems plain that a potential corporate defendant that might commit civil wrongs that would qualify for class action treatment cannot immunize itself from class actions by putting a clause in an adhesion contract barring a customer or employee from ever bringing a class action against it. That said, it is difficult to see why a drafter should be able to achieve the same result using an arbitration clause as the vehicle. The argument in favor of enforcing a class action ban in an arbitration agreement is that an arbitrator is not authorized to exceed his contractual authority by imposing a remedy beyond the bounds of the contract. ${ }^{214}$ But if class action is a remedy with substantive implications, a drafter has no more right to use an arbitration clause to exempt itself from class liability than from extracontractual damages. ${ }^{215}$ It might also be said that class actions are a procedure, and not a remedy, but this too is more false than true. The substantive implications of the class action remedy have been widely recognized. ${ }^{216}$ It is also the case that class actions plainly serve a private attorney general function, in which the lead plaintiffs and class counsel are implementing a public policy that goes beyond the individual plaintiff's claim. In this sense a class action is more like an Equal Employment Opportunity Commission ("EEOC") enforcement action than a private, bilateral arbitration. The Court, in EEOC v. Waffle House, ${ }^{217}$ held pre-dispute arbitration clauses were ineffective to

Fin'l v. Bazzle, 123 S. Ct. 2402, 2410-11 (2003) (Rehnquist, C.J., dissenting) (arguing that drafting party has right under FAA to preclude class actions).

214. See, e.g., Volt, 489 U.S. at 479 ("Arbitration under the [FAA] is a matter of consent, not coercion, and parties are generally free to structure their arbitration agreements as they see fit."); FAA $\$ 10(a)(4), 9$ U.S.C. $\$ 10(a)(4)$ (2001) (arbitration award may be vacated "where the arbitrators exceeded their powers").

215. It can, of course, be argued that an arbitrator likewise lacks authority to bind nonparties to the agreement. But this argument only applies against class-wide arbitrations. The argument here is that class actions-or at least class liability issues-can not be contracted away in an arbitration agreement and must be decided in court, rather than arbitration.

If an arbitrator were to hold a class arbitration, as in Bazzle, the argument about binding non-parties is somewhat misleading. Anyone who had no arbitration agreement with the defendant should perforce be excluded from the class. The defendant's objection in Bazzle was based on an asserted right to choose a different arbitrator, case-by-case, with every putative class member. See Bazzle, $123 \mathrm{~S}$. Ct. at 2411 . Even if that right to choose is sufficiently weighty an interest to preclude class arbitration, it does not seem sufficient to overcome the public interest in judicial class action enforcement of public laws.

216. See supra text accompanying notes $45-46$.

217. 534 U.S. 279 (2002). 
prevent the EEOC from pursuing even individual relief on behalf of an employee who is a party to an arbitration agreement. ${ }^{218}$

Based on these grounds, courts would be well justified in striking down class action bans as unconscionable or void as against public policy. But suppose that an "enforce as written" regime is imposed that prohibits class arbitration, yet also prohibits striking the arbitration agreement in its entirety. Must the result necessarily be immunity from class actions? The apparent choice-class arbitration or class litigation-leaves out a third possibility, suggested by a collateral estoppel approach. A plaintiff with potential class claims has an individual claim, but also a representative claim. An arbitration of the individual claim, where the arbitrator is not authorized to award class relief, is like the arbitration of a contract claim where the tort claim is reserved for the court due to an exclusion of extra-contractual damages. The arbitrator cannot adjudicate the plaintiff's representative claim. If the arbitrator finds liability, the plaintiff should not be collaterally estopped from litigating classwide liability. Indeed, the question of liability to a class is always separate from liability to any individual class member-the latter question being typically reserved for individual claims proceedings. Thus, an individual arbitration agreement should not divest a court of its jurisdiction over the class liability issue even under the Byrd rule, which holds only that an individual's arbitrable claims must precede his non-arbitrable claims. Class liability is not, technically, an individual's liability claim. In any event, since Byrd did not arise in the class action context, it should not be deemed controlling on this point. In this light, the most sensible approach is for a court to certify a class and rule on classwide liability, using the arbitration agreements, if at all, to resolve the individual class members' claims.

\section{Conclusion}

The courts have been clear on one point about remedy-stripping arbitration clauses: they cannot be enforced-as intended by their drafters-to compel the non-drafting party to waive substantive rights and remedies. While the Supreme Court has been coy about deciding the question once and for all, it has always said that claims can be compelled into arbitration under pre-dispute agreements because the parties to arbitration do not forego substantive rights. That assertion implies the converse: arbitration cannot be compelled where the ef-

218. See id. at 297. 
fect would be the waiver of such rights. But the judicial strategies to deny enforcement of remedy-stripping clauses have varied: denying enforcement of the arbitration clause as a whole, on unconscionability grounds; compelling some claims, but refusing to compel others, into arbitration, on issue-arbitrability grounds; or rewriting the contract to permit arbitration of all claims without limiting any remedies. The most common judicial strategy seems to be the middle, "arbitrability" approach, which results in a partial arbitration with issues left over to be litigated. Such partial enforcement of remedy-stripping clauses raises significant preclusion issues that have remained largely undeveloped in the doctrine of arbitration agreements.

I have argued, in essence, that in deciding the enforcement question and any subsequent preclusion issues, courts should be guided by a policy of deterrence. Remedy-stripping arbitration clauses are attempts to misuse the judicially favored arbitration vehicle to violate public policy. The only way to discourage such drafting is to impose penalties at the contract interpretation/enforcement stage. A finding that the arbitration clause is invalid as a whole will be the best deterrent in most cases.

Can it be said that remedy-stripping arbitration clauses are less onerous in light of background preclusion principles that would protect plaintiffs from forced waivers of claims and remedies? Perhaps so-but not so as to make an otherwise unconscionable remedy-stripping clause fair enough to be enforceable. After all, it remains clear that the drafter's intent in a remedy-stripping clause is to impose the waiver of remedies rather than, under the alternate reading, simply to limit arbitrable issues. Drafters who sincerely wish to limit issues to be submitted to the arbitrator can specify clearly those claims that will be arbitrated and those that will not be. Even drafters who hope to bifurcate liability and remedy by assigning liability questions to the arbitrator can clearly draft that intent. Thus, even with the background preclusion principles that would protect against waivers of remedies, courts are still justified in holding remedy-stripping arbitration clauses unenforceable in their entirety.

Where partial enforcement seems appropriate, however, the policy of deterrence can be implemented by giving the prior arbitration the narrowest scope consistent with existing preclusion principles. Current FAA doctrine makes clear that drafting parties have essentially unilateral power to impose their choice of arbitration over litiga- 
tion on their customers, franchisees, and employees. But giving drafters that choice is not an open invitation to structure the arbitration process to immunize themselves from their own violations of law. 
